\title{
1 Life Cycle Assessment of residential streets from the perspective of favoring \\ 2 the human scale and reducing motorized traffic flow. From cradle to \\ 3 handover approach
}

4

5

\begin{abstract}
A B S T RA C T
Currently, few studies have compared the variations in environmental impact throughout the different stages of the life cycle of urban construction elements; and of these, only a minority approach it from the perspective of favoring mobility on a human scale and reducing the space allocated to motorized traffic flow.

This study, by means of quantitative data, shows the environmental implications associated with prioritizing the non-motorized mobility of a city's inhabitants during the design process of an urban construction element, the residential street (referring to the stages of the production and the construction process: the "cradle to handover" approach). An emerging methodology in urban themes was used in order to obtain the environmental analysis: Life Cycle Assessment (LCA).

The results show that the increase in the human scale and the favoring of non-motorized mobility generate a lower environmental impact (considering the same uses of materials for the different zones of analysis). Additionally, it was possible to establish the influence that the specific use of materials employed in the construction of the streets may have, as well as the importance that an LCA acquires in the design of the urban environment.
\end{abstract}

Keywords: Cradle to handover; Ecoindicator 99; Environmental impacts; Life cycle assessment; Nonmotorized traffic flow; Pedestrian environment; Street design; Street materials; Sustainable cities; Urban planning.

\section{Introduction}

The street is one of the principal elements that define the configuration of the urban environment: "Streets lie at the heart of communities, shape human health and environmental quality, and serve as the foundation of urban economies. In many cities, streets make up more than $80 \%$ of all public space, and collectively have the potential to foster business activity" (GDCI \& NACTO, 2016). Several researchers (Gilderbloom et al., 2015; Haider et al., 2018; Kwan \& Hashim, 2016; Lindelöw et al., 2014) show the advantages that can accrue from an 
environment in which the human scale is prioritized during the design process of urban planning.

In recent years, aspects related to the analysis of streets, which favor a pedestrian environment over motorized traffic flow, have been studied and developed. Nevertheless, the majority of studies carried out focus exclusively on the usage stage, neglecting to use integral environmental data from the complete life cycle (Mendoza, Oliver-Solà, Gabarrel, Rieradevall, \& Josa, 2012). If used, this data would allow the environmental load produced in the various stages of the life cycle of a specific street to be known from the design process.

Some of the studies which justify the consideration of environmental criteria (Araújo et al., 2014; Loijos et al., 2013; Mendoza, Oliver-Solà, Gabarrel, Rieradevall, \& Josa, 2012; Noshadravan et al., 2013; Oliver-Solà et al., 2009) focus on comparisons and the exclusive implications involved in choosing the materials for a specific section of the street (usually sidewalks or travel lanes). However, from the perspective of favoring the human scale and reducing the space allocated to motorized traffic, no evidence has been found about the figures or proportions that show the possible environmental impact of the stages incorporated in the streets.

Therefore, the aim of this work is, using quantitative data, to show the environmental ramifications when priority is given to the inhabitants of a city during the design process of a street (referring to production and construction stages: the "cradle to handover" approach). To achieve this objective, a methodology has been used with which it is expected to obtain a greater perspective of its use in the urban environment: LCA.

The analysis compares the environmental behavior of 18 options that are grouped into three types of residential street sections: the conventional, favoring motor traffic flows, and two 


\section{Method and data}

\subsection{Description of Life Cycle Assessment}

\subsubsection{Aim and scope}

The defined aim of the LCA is to compare three street sections whose width varies as a result of favoring motorized and non-motorized flows, as well as the different materials they are made from. The aim of the study is to establish the possible environmental impacts generated by the different streets, in addition to finding the most environmentally suitable combination of materials and sections.

Previous works have related the "cradle to handover" perspective (or similar: "cradle to gate" and "cradle to site" (Malmqvist et al., 2018)) with the objective of providing information which contributes to defining the repercussions of the construction itself. Some recent manuscripts, which have considered these limits of the system, are listed in Table 1. In this sense, this research is a "cradle to handover" study -according to Annex 57 of the International Energy Agency (Seo et al., 2016)-, which includes the production stages: extraction of the raw materials (A1), transport (A2) and production of the materials (A3). It also includes the construction process stage, which is composed of: transport from production to the site (A4) as well as the building process itself (A5) - according to the Norm UNE-EN 15804 (AENOR, 2014)-. Fig. 1 shows the analysis of the flow in the life cycle inventory (LCI) used in this study.

\section{Table 1}

LCA studies that consider the stages directly related to the construction process.

\begin{tabular}{lll}
\hline Stage & Authors & Highlights \\
\hline Cradle to gate & (Cass \& Mukherjee, 2011) & Development of a method that quantifies pavement life cycle emissions. \\
(A1-A3) & (Moretti et al., 2018) & Analysis of environmental impacts of two types of road cross-sections. \\
& (Sandanayake et al., 2018) & Comparison of greenhouse gas (GHG) emissions and energy consumption in wood and \\
& concrete buildings.
\end{tabular}




$\begin{array}{lll}\begin{array}{l}\text { Cradle to site } \\ \text { (A1-A3+A4) }\end{array} & \text { Development of an embodied carbon prediction tool for conventional housing. } \\ \text { Cradle to handover } & \text { (Smith \& Durham, 2016) } & \text { Environmental evaluation of pavements considering economic, environmental and } \\ \text { (A1-A3+A4-A5) } & \text { mechanical performance criteria. } \\ & \text { (Mohajerani et al., 2018) } & \text { Evaluation of the impacts generated by the incorporation of biosolids in conventional } \\ & \text { materials. }\end{array}$

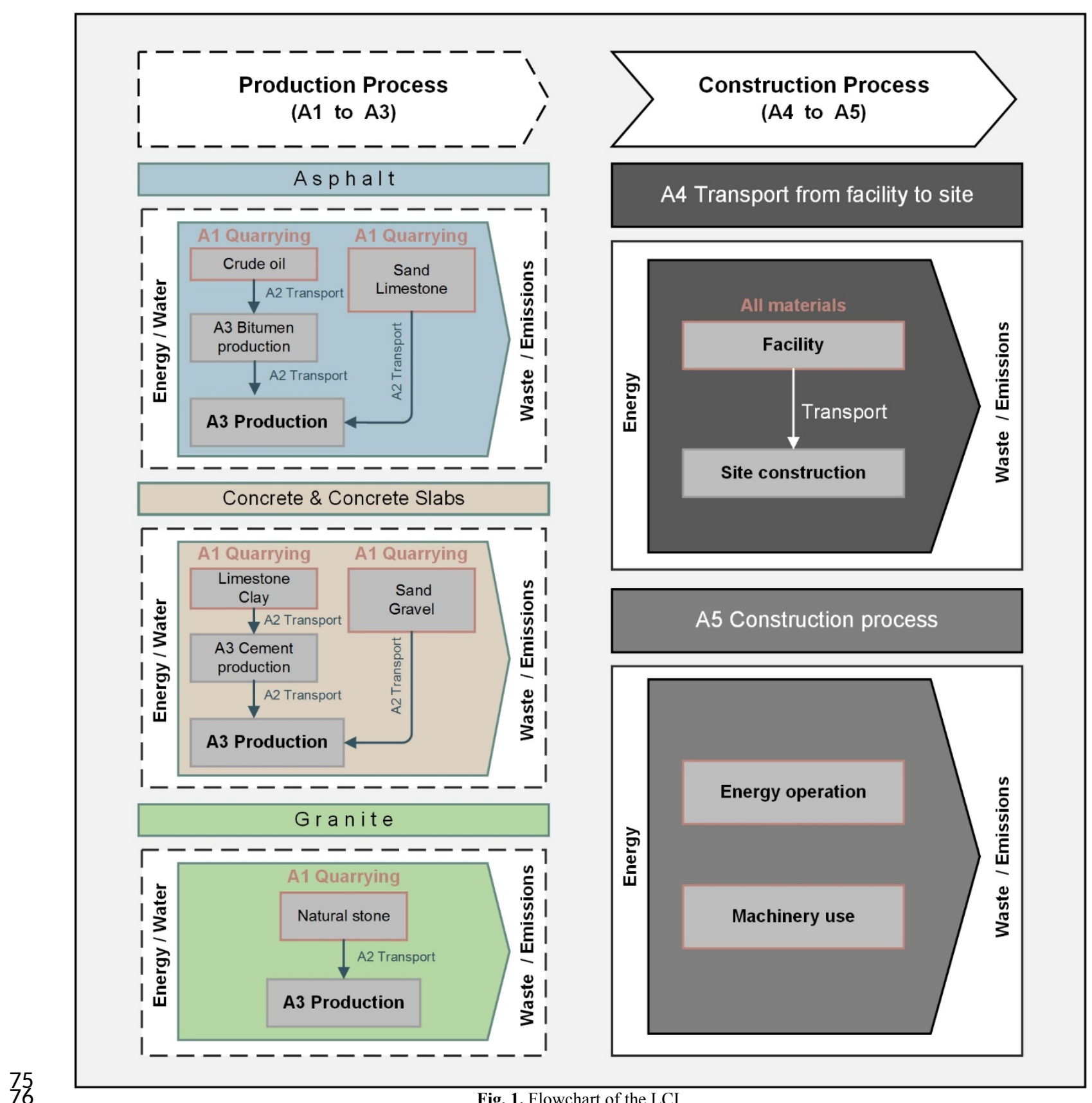

Fig. 1. Flowchart of the LCI.

77 Additionally, according to the configurations established from the streets under study, the 78 linear meter $(\mathrm{ml})$ was the functional unit, since it is the one that best defines the evaluation of 
the environmental impacts of each integrated zone. Previous research (Moretti et al., 2018; Petit-Boix et al., 2014) confirms that this functional unit is a reliable and objective parameter in this type of analysis. A constant total width of 13 meters was considered for the 18 options.

\subsubsection{Data inventory}

The Ecoinvent database, recognized internationally as a source of consistent and updated data (Frischknecht et al., 2007), was used to obtain the LCI. Applied to the field of research it mostly deals with information related to the European region, and it has been widely used in previous LCA studies (García-Guaita et al., 2018; Heinonen et al., 2016; Ortíz et al., 2010; Thiers \& Peuportier, 2012).

The BEDEC materials database (ITEC, 2017) was used to quantify the materials and energy of the processes needed to develop stages A1-A5 of each street. The BEDEC database incorporates elements and construction materials of different types, whose technical characteristics belong in praxis to the Spanish ambit.

\subsubsection{Impact assessment method and categories}

The results of the environmental impact were processed using the Software LCA Manager 1.3 (Simpple, 2010), which allows the resources used and their environmental effects to be analyzed by means of the LCA methodology (AENOR, 2006). LCA Manager 1.3 has been used in previous research (Ortiz et al. 2010), with the results confirming its reliability.

The environmental impact method chosen was Ecoindicator 99, recognized as being one of the most used in performing the LCA. Ecoindicator 99 allows the environmental load of a product or process to be expressed as an individual score (Pré consultants, 2018). This method has been used in previous studies with reliable and comparable results (Biswas et al., 2017;

Faludi et al., 2012; Kellenberger \& Althaus, 2009; Pushkar, 2014; Sianipar \& Dowaki, 2014). 
The included categories of environmental impact are of global interest and are grouped in the following areas of protection (AoP):

- Ecosystem quality (EQ): acidification-eutrophication, ecotoxicity and land occupation.

- Human health $(\mathrm{HH})$ : carcinogenics, climate change, ionizing radiation, ozone layer depletion and respiratory effects.

- Resources (RS): fossil fuels and mineral extraction.

\subsection{Life cycle inventory}

\subsubsection{Production stages (A1-A3)}

In the analysis of stages A1-A3, a study was made of all the materials of each street configuration that generated variations in the results. They were then used to conform the travel lane (TL), the pedestrian zone (PZ), the buffer zone (BZ) and the bicycle lane (BL), as well as the materials used in the lower layers (base and sub-base). The materials omitted from this study were those used for the curbs and those related to urban installations and fixtures (common elements in all the options studied, which do not show variations in the comparative analysis). The data for quantifying the materials was obtained from BEDEC and adapted to the characteristics of this study, for stages A1-A3 as well as for stage A5.

The streets are built of the typical inert materials most commonly used in construction. Most are petrous in origin: limestone, clays, sands, gravel, granites, and artificial and natural graded aggregates, among others; the exception is mastic asphalt, which contains the petroleum derivative bitumen. All of them are available as construction materials in Ecoinvent. The necessary quantity of each of these materials was obtained in order to make a linear meter of each option (1x13m), and then a waste coefficient (ITEC, 2017) was applied to them. Table 2 shows the data used for the analyzed stages (A1-A3, and A4-A5) and the Ecoinvent datasets. 
LCI for functional unit (one linear meter) of each street zone

\begin{tabular}{|c|c|c|c|c|c|c|c|c|c|c|c|c|c|c|c|c|c|c|c|}
\hline \multirow{2}{*}{ Stage } & \multirow[t]{2}{*}{ Material/process } & \multicolumn{5}{|c|}{ Conventional } & \multicolumn{5}{|c|}{ Redesign A } & \multicolumn{7}{|c|}{ Redesign B } & \multirow[t]{2}{*}{ Ecoinvent material/process } \\
\hline & & $\begin{array}{l}\mathrm{TL} \\
\text { Asphalt }\end{array}$ & $\begin{array}{l}\mathrm{TL} \\
\text { Concrete }\end{array}$ & $\begin{array}{l}\mathrm{PZ}+ \\
\mathrm{BZ} \\
\text { Asphalt }\end{array}$ & $\begin{array}{l}\mathrm{PZ}+\mathrm{BZ} \\
\text { Concrete }\end{array}$ & $\begin{array}{l}\text { PZ+BZ } \\
\text { Granite }\end{array}$ & $\begin{array}{l}\mathrm{TL}+\mathrm{PL} \\
\text { Asphalt }\end{array}$ & $\begin{array}{l}\mathrm{TL}+\mathrm{PL} \\
\text { Concrete }\end{array}$ & $\begin{array}{l}\mathrm{PZ}+ \\
\mathrm{BZ} \\
\text { Asphalt }\end{array}$ & $\begin{array}{l}\mathrm{PZ}+\mathrm{BZ} \\
\text { Concrete }\end{array}$ & $\begin{array}{l}\text { PZ+BZ } \\
\text { Granite }\end{array}$ & $\begin{array}{l}\mathrm{TL} \\
\text { Asphalt }\end{array}$ & $\begin{array}{l}\text { TL } \\
\text { Concrete }\end{array}$ & $\begin{array}{l}\mathrm{PZ}+ \\
\mathrm{BZ} \\
\text { Asphalt }\end{array}$ & $\begin{array}{l}\mathrm{PZ}+\mathrm{BZ} \\
\text { Concrete }\end{array}$ & $\begin{array}{l}\text { PZ+BZ } \\
\text { Granite }\end{array}$ & $\begin{array}{l}\text { BL } \\
\text { Asphalt }\end{array}$ & $\begin{array}{l}\text { BL } \\
\text { Concrete }\end{array}$ & \\
\hline \multirow{9}{*}{$\begin{array}{l}\text { A1- } \\
\text { A3 }\end{array}$} & Water $(\mathrm{kg})$ & 89.78 & 60.38 & 34.50 & - & 25.20 & 70.54 & 47.44 & 38.81 & - & 28.35 & 38.48 & 25.88 & 43.13 & - & 31.50 & 18.11 & 12.08 & Tap water, at user \\
\hline & Coarse aggregates (ton) & 3.98 & 2.05 & 1.17 & - & - & 3.13 & 1.61 & 1.32 & - & - & 1.71 & 0.88 & 1.47 & - & - & 0.62 & 410.55 & Gravel, crushed, at mine \\
\hline & Cement (kg) & 129.65 & - & - & - & 31.50 & 101.87 & - & - & - & 35.44 & 55.57 & - & - & - & 39.38 & - & - & Portland cement, strength class $Z 42.5$, at plant \\
\hline & Concrete base $\left(\mathrm{m}^{3}\right)$ & - & - & - & 0.42 & 0.42 & - & - & - & 0.47 & 0.47 & - & - & - & 0.53 & 0.53 & - & - & Concrete, normal, at plant \\
\hline & Fine aggregates $(\mathrm{kg})$ & - & - & - & 24.81 & 205.38 & - & - & - & 27.91 & 231.05 & - & - & - & 31.01 & 256.73 & - & - & Silica sand, at plant \\
\hline & Asphalt (kg) & 540.23 & - & 220.50 & - & - & 424.46 & - & 248.06 & - & - & 231.53 & - & 275.63 & - & - & 115.76 & - & Mastic asphalt, at plant \\
\hline & $\begin{array}{l}\text { Concrete/concrete slabs } \\
\left(\mathrm{m}^{3}\right)\end{array}$ & - & 1.32 & - & 0.33 & - & - & 1.04 & - & 0.37 & - & - & 0.57 & - & 0.41 & - & - & 0.35 & Concrete, exacting, at plant \\
\hline & Granite slabs (kg) & - & - & - & - & 742.56 & - & - & - & - & 835.38 & - & - & - & - & 928.20 & - & - & Natural stone plate, polished, at regional storage \\
\hline & Sand $(\mathrm{kg})$ for BZ & - & - & 444.00 & 473.60 & 444.00 & - & - & 744.00 & 793.60 & 744.00 & - & - & 714.00 & 875.60 & 714.00 & - & - & Silica sand, at plant \\
\hline $\mathrm{A} 4$ & Operation lorry (tkm) & 253.40 & 181.38 & 101.87 & 77.11 & 87.78 & 199.10 & 142.51 & 129.27 & 102.39 & 113.42 & 108.60 & 77.73 & 136.88 & 113.40 & 119.26 & 39.50 & 41.71 & Transport, lorry 16-32t, EURO5 \\
\hline \multirow[t]{3}{*}{ A5 } & Machinery E10-6 (unit) & 20.56 & 38.80 & 7.65 & 0.65 & 8.82 & 16.15 & 30.49 & 8.61 & 0.73 & 9.92 & 8.81 & 16.63 & 9.56 & 0.82 & 11.03 & 4.02 & 9.54 & Building machine \\
\hline & Energy $(\mathrm{kg})$ & 2.38 & 2.46 & 0.86 & 0.01 & - & 1.87 & 1.93 & 0.97 & 0.01 & - & 1.02 & 1.06 & 1.07 & 0.01 & - & 0.45 & 0.57 & Diesel, at regional storage \\
\hline & Energy (kWh) & - & - & - & - & 0.06 & - & - & - & - & 0.07 & - & - & - & - & 0.08 & - & - & Electricity, low voltage, production ES, at grid / ES \\
\hline
\end{tabular}


The transport from the factory to the site stage (A4) studies the impact connected with the operation $\left(\mathrm{O}_{\mathrm{L}}\right.$ in tkm) of the transport vehicle used, by means Eq. (1).

$$
O_{L}=W D
$$

Where $\mathrm{W}$ is the weight required by the functional unit for each material used in making the street; $\mathrm{D}$ is the distance from the factory to the roadworks. The average distance from a minimum of two factories to the final reference point (the theoretical center of Barcelona city, Plaza Cataluña) was evaluated as D. The values of D were obtained using Google Maps as a georeferencing system and were as follows: $60 \mathrm{~km}$ for aggregates, $40 \mathrm{~km}$ for concrete and granite slabs, $20 \mathrm{~km}$ for cement, concrete and asphalt. The lorry chosen for the transport complied with all the specifications of weight and maximum size for short journeys, as established by the Spanish Ministry of Development (Ministerio de Fomento, 2017).

The usage share of the machinery (PU $\mathrm{P}_{\mathrm{M}}$, Eq. (2)) was evaluated for the construction process stage (A5), as well as the operating energy ( $\mathrm{E}_{\mathrm{O}}$ in $\mathrm{kg}$ of diesel or $\mathrm{kWh}$, as the case may be) of the machinery used in building each option (Eq. (3)).

$$
P U_{M}=\left(T U / U L_{M}\right)
$$

$$
E_{O}=T U x P_{M}
$$

Where TU is the usage time of each machine; $\mathrm{UL}_{\mathrm{M}}$ is the useful life of the machine equal to 10,000 h (Frischknecht et al., 2007); and $\mathrm{P}_{\mathrm{M}}$ can be either the fuel or the machine's potency, depending on the situation; the machinery's consumption needs are shown in Table 3.

\section{Table 3}

Fuel consumption or potency of machinery. 


\begin{tabular}{ll}
\hline Machine & Fuel consumption $(\mathrm{kg} / \mathrm{h})$ \\
& or potency $(\mathrm{kW})$ \\
\hline Tanker truck $10 \mathrm{~m}^{3}$ & 8.3 \\
Vibratory roller & 10.8 \\
Motor Grader & 14.1 \\
Dumper & 2.2 \\
Asphalt paver & 8.7 \\
Concrete paver & 11.4 \\
Vibrating tray & 1.2 \\
Concrete mixer & 0.7 \\
\hline
\end{tabular}

\subsection{Case studies description}

Three types of sections (Fig. 2) were designed, referring to types of secondary streets for a residential area (GDCI \& NACTO, 2016); one conventional (CO) and two redesigned (RA and RB). Each study section can be described as follows: (i) in the reference case CO, priority is given to the TL for motorized vehicular traffic, while the pavements (PZ and BZ) comply with

159 the minimum widths recommended by the Global Designing Cities Initiative (GDCI) and the

160 National Association of City Transportation Officials (NACTO). (ii) In the RA case, emphasis

161 is laid on increasing the widths of PZ and BZ, and the space dedicated to motorized traffic flow

162 is composed of a TL and a parking lane (PL). Finally, (iii) the section of the RB cases is 163 designed to be as respectful as possible to the alternatives to motorized transport. In this last 164 case, unlike the others, only one TL is included; and so the areas dedicated to PZ, including the BL in both directions, are increased. 


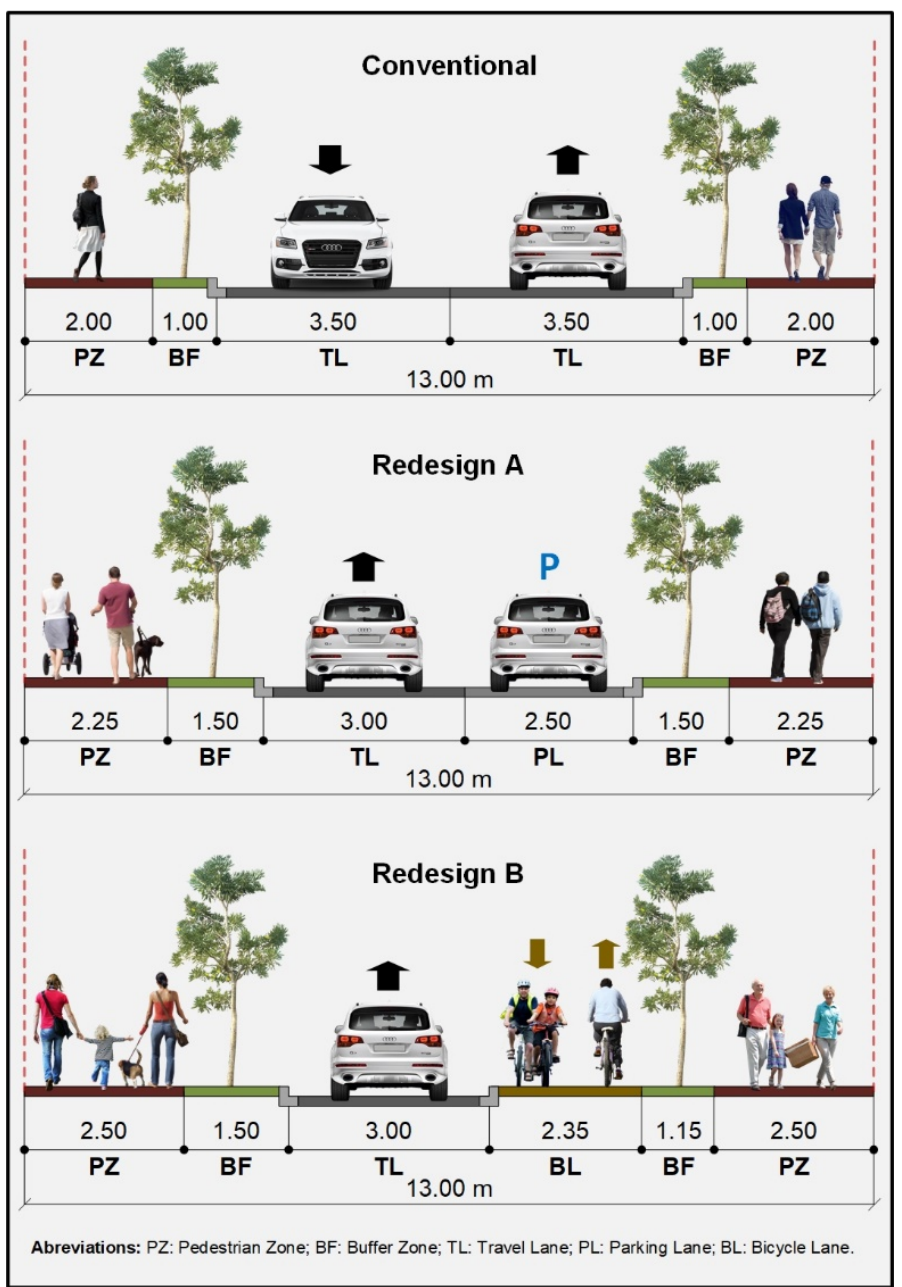

Fig. 2. Street sections (CO, RA y RB).

168 By means of alterations in their constituent materials, the three sections to be studied were 169 also evaluated to determine the environmental effects they might provoke. The materials used 170 were of the type commonly used as street components in European urban environments: two

171 for TL (asphalt and concrete); three for PZ (asphalt, concrete slabs and granite slabs); two for 172 (asphalt and concrete) and finally, one for BZ (silica sand). Fig. 3 details the design composition 173 of each material variation used, all satisfying the established requirements for their application 174 (Alabern i Valentí \& Guilemany i Casadamon, 1999; MAC, 2018). 
Sidewalk layers:

Asphalt (PZ \& BL):

Mastic asphalt, $2.5 \mathrm{~cm}$;

Granular base, $15 \mathrm{~cm}$;

Subgrade

Concrete slabs (PZ):

Concrete slabs, $6 \mathrm{~cm}$;

Granular base, $15 \mathrm{~cm}$

Subgrade

Granite (PZ):

Granite slabs, $7 \mathrm{~cm}$

Mortar base, $3 \mathrm{~cm}$;

Concrete base, $10 \mathrm{~cm}$

Subgrade

Concrete (BL):

Concrete layer, $16 \mathrm{~cm}$

Granular base, $10 \mathrm{~cm}$;

Subgrade
Street layers:

Asphalt (TL \& PL)

Mastic asphalt, $3.5 \mathrm{~cm}$;

Granular base, $20 \mathrm{~cm}$;

Sub-base material, $15 \mathrm{~cm}$

Subgrade

Concrete (TL \& PL):
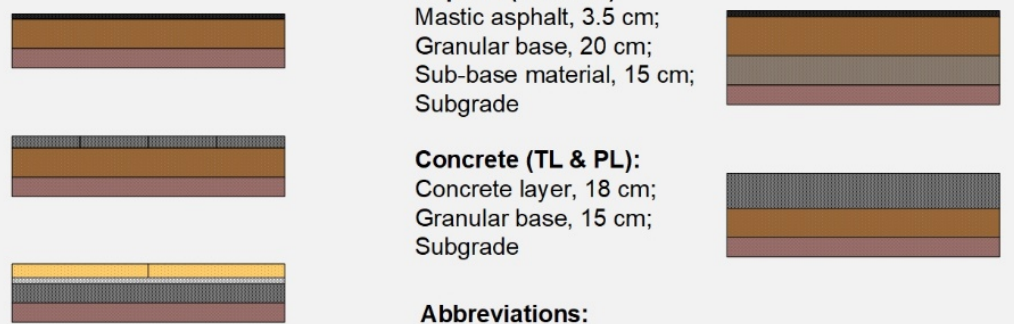

Concrete layer, $18 \mathrm{~cm}$;

Granular base, $15 \mathrm{~cm}$;

Subgrade

Abbreviations:

Bicyle Lane (BL)

Parking Lane (PL)

Pedestrian Zone (PZ)

Travel Lane (TL)
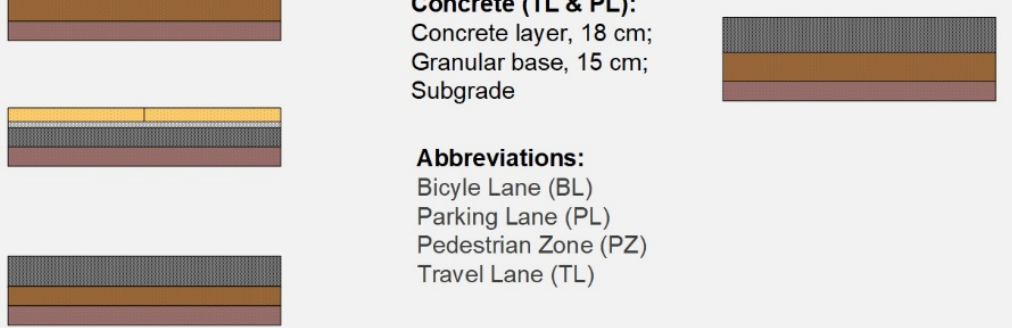

Fig. 3. Detail of surfaces for TL, PZ and BL.

The combination of the three types of section and the different materials produces 18 different case studies (Table 4).

Table 4

Case studies description.

\begin{tabular}{|c|c|c|c|}
\hline Typology & Case & Zone - Total Width (m) - Material & $\begin{array}{l}\text { Most common material in: } \\
\text { MF }^{\mathrm{A}} \text { zones }-\mathrm{GM}^{\mathrm{B}} \text { zones }\end{array}$ \\
\hline \multirow[t]{6}{*}{ Conventional } & 1 & TL-7.00-Asphalt; PZ-4.00-Asphalt; BZ-2.00-Sand & Asphalt - Asphalt \\
\hline & 2 & TL-7.00-Asphalt; PZ-4.00-Concrete; BZ-2.00-Sand & Asphalt - Concrete \\
\hline & 3 & TL-7.00-Asphalt; PZ-4.00-Granite; BZ-2.00-Sand & Asphalt - Granite \\
\hline & 4 & TL-7.00-Concrete; PZ-4.00-Asphalt; BZ-2.00-Sand & Concrete - Asphalt \\
\hline & 5 & TL-7.00-Concrete; PZ-4.00-Concrete; BZ-2.00-Sand & Concrete - Concrete \\
\hline & 6 & TL-7.00-Concrete; PZ-4.00-Granite; BZ-2.00-Sand & Concrete - Granite \\
\hline \multirow[t]{6}{*}{ Redesign A } & 7 & TL \& PL-5.50-Asphalt; PZ-4.50-Asphalt; BZ-3.00-Sand & Asphalt - Asphalt \\
\hline & 8 & TL \& PL-5.50-Asphalt; PZ-4.50-Concrete; BZ-3.00-Sand & Asphalt - Concrete \\
\hline & 9 & TL \& PL-5.50-Asphalt; PZ-4.50-Granite; BZ-3.00-Sand & Asphalt - Granite \\
\hline & 10 & TL \& PL-5.50-Concrete; PZ-4.50-Asphalt; BZ-3.00-Sand & Concrete - Asphalt \\
\hline & 11 & TL \& PL-5.50-Concrete; PZ-4.50-Concrete; BZ-3.00-Sand & Concrete - Concrete \\
\hline & 12 & TL \& PL-5.50-Concrete; PZ-4.50-Granite; BZ-3.00-Sand & Concrete - Granite \\
\hline \multirow[t]{6}{*}{ Redesign B } & 13 & TL-3.00-Asphalt; PZ-5.00-Asphalt; BL-2.35-Asphalt; BZ-2.65-Sand & Asphalt - Asphalt \\
\hline & 14 & TL-3.00-Asphalt; PZ-5.00-Concrete; BL-2.35-Concrete; BZ-2.65-Sand & Asphalt - Concrete \\
\hline & 15 & TL-3.00-Asphalt; PZ-5.00-Granite; BL-2.35-Asphalt; BZ-2.65-Sand & Asphalt - Granite \\
\hline & 16 & TL-3.00-Concrete; PZ-5.00-Asphalt; BL-2.35-Asphalt; BZ-2.65-Sand & Concrete - Asphalt \\
\hline & 17 & TL-3.00-Concrete; PZ-5.00-Concrete; BL-2.35-Concrete; BZ-2.65-Sand & Concrete - Concrete \\
\hline & 18 & TL-3.00-Concrete; PZ-5.00-Granite; BL-2.35-Concrete; BZ-2.65-Sand & Concrete - Granite \\
\hline
\end{tabular}

The information in table 4 is organized into six comparative groups (Table 5) taking into 
comparing the environmental consequences of increasing the percentage aimed at the human scale in a specific residential street, without the differences in materials being a factor of variability.

188 Comparatives showing similar ratios of materials.

\begin{tabular}{|c|c|c|}
\hline Comparative & $\begin{array}{l}\text { Most common material in: } \\
\mathrm{MF}^{\mathrm{A}} \text { zones }-\mathrm{GM}^{\mathrm{B}} \text { zones }\end{array}$ & Case - Section typology \\
\hline C-1 & Asphalt - Asphalt & 1-CO ; 7-RA ; 13-RB \\
\hline $\mathrm{C}-2$ & Asphalt - Concrete & 2-CO ; 8-RA ; 14-RB \\
\hline C-3 & Concrete - Concrete & 5-CO ; 11-RA ; 17-RB \\
\hline C-4 & Concrete - Asphalt & 4-CO ; 10-RA ; 16-RB \\
\hline C-5 & Asphalt - Granite & 3-CO ; 9-RA ; 15-RB \\
\hline C-6 & Concrete - Granite & 6-CO ; 12-RA ; 18-RB \\
\hline
\end{tabular}

${ }^{\mathrm{A}}$ Motorized flow; TL \& PL ${ }^{\mathrm{B}}$ Green mobility; PZ \& BL.

\section{Results and discussion}

In this study it was found that prioritizing the human scale leads to a reduction in the environmental impact, as long as conventional materials such as concrete and asphalt are used in configuring residential streets. In the graphs of the comparative groups C1-C4 (Fig. 4), it can

194 be seen that an $11.54 \%$ increase in the areas destined for human scale (RA cases) may generate 195 reductions of between 6.94\% (C-4) and 11.09\% (C-2). Meanwhile, an increase of 30.77\% 196 (including 18\% of the space destined for BL) may generate reductions of between 9.49\% (C-4) and $22.27 \%(\mathrm{C}-2)$ in the total environmental impact (RB cases). 


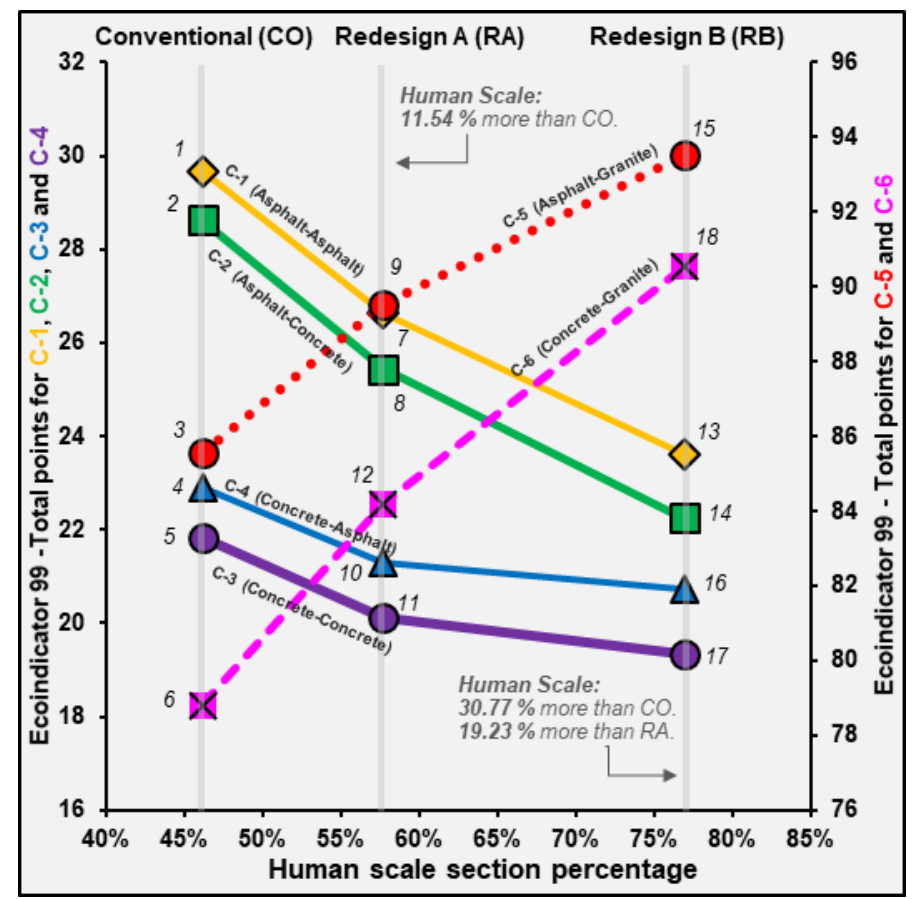

Fig. 4. Comparisons between cases showing similar ratios of materials.

Fig. 4 also shows that, unlike the results of the C1-C4 groups, the use of granite increases the environmental impact even when the human scale is favored. For instance, if the RA sections are used, the environmental impact is increased by $4.61 \%$ in $\mathrm{C}-5$ and $6.85 \%$ in $\mathrm{C}-6$; in the case of the RB sections the increases are $9.26 \%$ in C-5 and $14.90 \%$ in C-6, all in respect of the $\mathrm{CO}$ sections. This shows that the use of granite (as well as its production) generates important environmental issues and therefore, as there are alternative materials with equivalent functional and service capacities, the use of granite should be limited in configuring residential streets.

A comparison is made in Fig. 5 between cases 11 of the RA and 17 of the RB, the cases with the best general environmental performance, and the six design cases $\mathrm{CO}(1-6)$. From this comparison it can be deduced that they establish a reductive environmental impact, which (i) ranges from $7.88 \%$ (case 5) to $76.50 \%$ (case 3 ) with regard to case 11 ; and (ii) from $11.44 \%$ the section that incentivizes greater non-motorized traffic flows (case 17; including BL) shows 
the best environmental behavior, reducing impacts by $3.86 \%$. This is congruent with Gehl's research (Gehl, 2010): “The desire for a healthy city is strengthened dramatically if walking or biking can be a natural part of the patterns of daily activities".

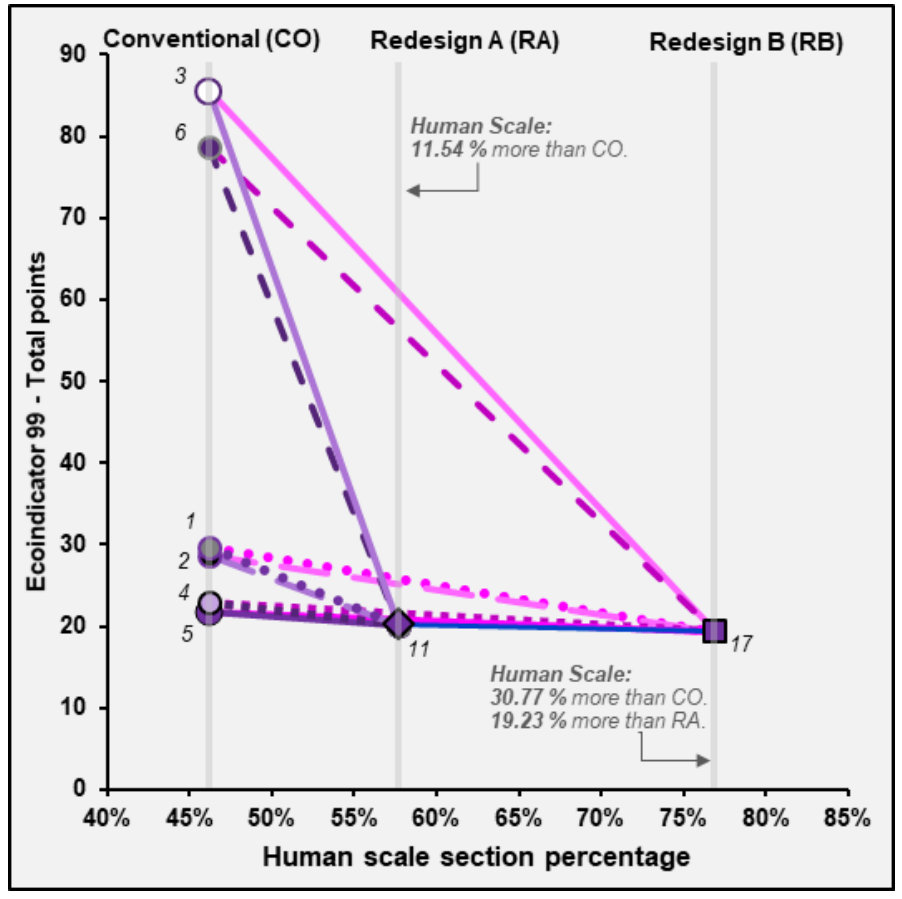

Fig. 5. Comparison of the $\mathrm{CO}$ cases (1-6) with those that produce less environmental impact in RA (11) and RB (17).

Similarly, the results of the case studies show the influence that the definition of the materials used in making the streets has; the use of granite in PZ (average of C5-C6) produces noticeable variations regarding the behavior of the cases in which it is not used (average of C1C4), increasing the total impact by $270 \%$ (Fig. 6). Previous studies have also shown that granite generates higher environmental loads in comparison to other materials used in urban infrastructure (Mendoza, Oliver-Solà, Gabarrel, Josa \& Rieradevall, 2012; Mendoza, Oliver-

Solà, Gabarrel, Rieradevall \& Josa, 2012). 


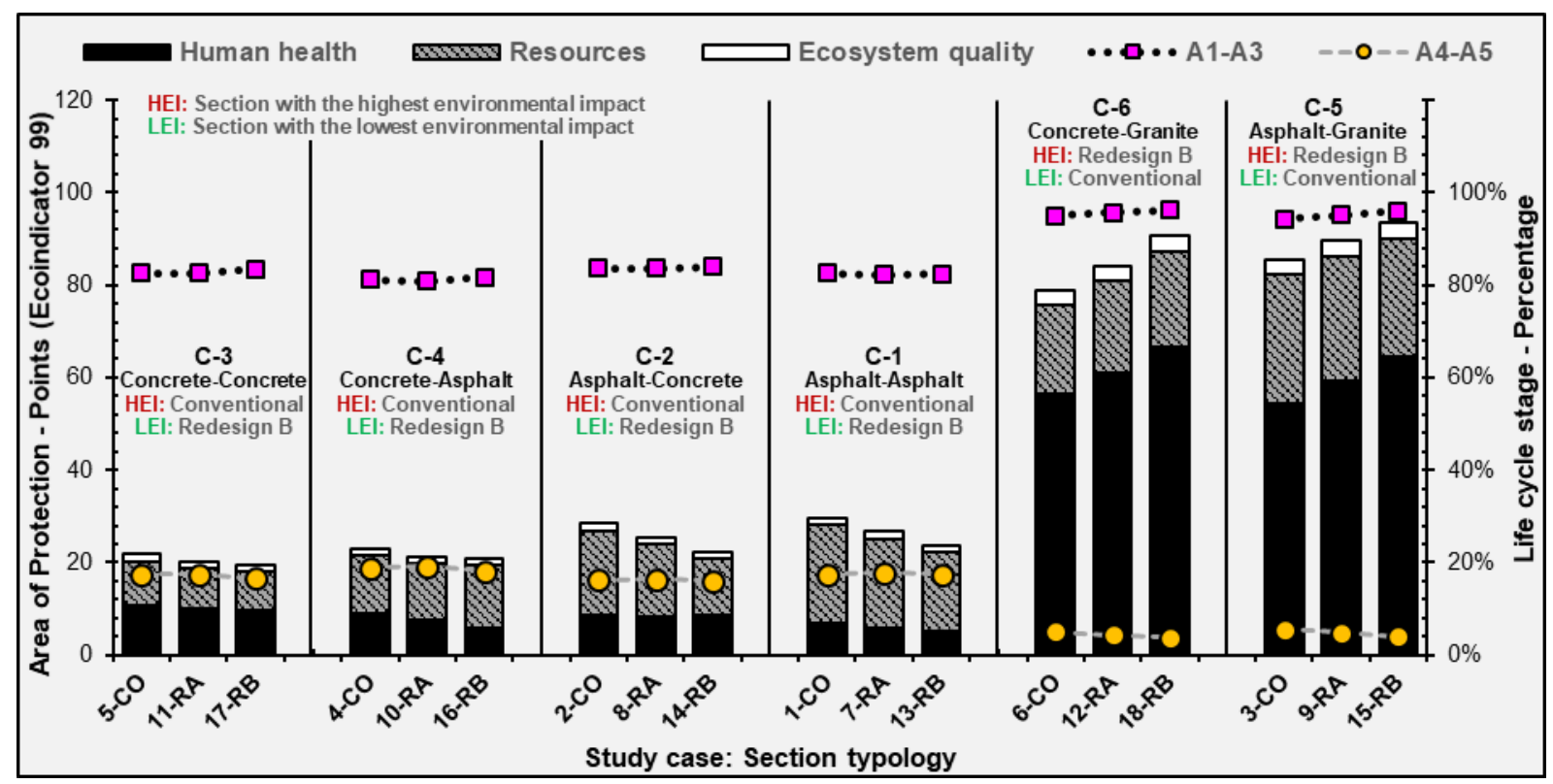

Fig. 6. Comparisons of the cases showing similar ratios of materials used.

Additionally, when comparing the cases that only used asphalt and concrete as materials in

all sections of the street (Fig. 6 and Table 6), it was seen that they affected each of the AoP

differently except for EQ, where the variation is reduced (2\%) in comparison with RS and HH.

Concrete generates $73 \%$ more impact on $\mathrm{HH}$, with its most important categories being the impact on climate change and its respiratory and carcinogenic side effects, which respectively produce $113 \%, 51 \%$ and $70 \%$ more impact than asphalt. Asphalt has a greater impact on the RS, generating $121 \%$ more fossil fuel consumption. Some authors agree with the previously established data, for example (Mendoza, Oliver-Solà, Gabarrel, Rieradevall \& Josa, 2012) contribution to global warming is lower.

Table 6

Values of Ecoindicator 99 for the most important impact categories for concrete and asphalt.

\begin{tabular}{lll}
\hline Impact Category & C-1 (Concrete) & C-3 (Asphalt) \\
\hline Carcinogenic & 1.06 & 0.59 \\
Climate change & 3.60 & 1.69 \\
Respiratory effects & 5.43 & 3.60 \\
Fossil fuels & 8.68 & 19.16 \\
Total & 20.43 & 26.65 \\
\hline
\end{tabular}


In the street sections where asphalt was used, the most affected AoP is RS ( $>70 \%)$, whereas for concrete and granite it is $\mathrm{HH}(\approx 50 \%, \approx 70 \%$, respectively; Fig. 6). These environmental implications occur in more than $80 \%$ of the A1-A3 stages (greater environmental implication); therefore, their influence will define and establish the complete environmental profile of each street, as has also been shown in previous studies (Cass \& Mukherjee, 2011).

In this study (Table 7 ), A1-A3 represents $\approx 85 \%$ for the cases $\mathrm{C} 1-\mathrm{C} 4$ and $\approx 96 \%$ for the cases of $\mathrm{C} 5$-C6, followed by A4 with $\approx 15 \%$ for $\mathrm{C} 1-\mathrm{C} 4$ and $\approx 4 \%$ for $\mathrm{C} 5-\mathrm{C} 6$; finally, there is $\mathrm{A} 5$, with less than $3 \%$ in all the cases. Although each study is limited by its own conditions, it is important should not be underestimated, as other studies have also concluded (Kellenberger \& Althaus, 2009).

Table 7

Values of Ecoindicator 99 for the AoP of the life cycle stages.

\begin{tabular}{|c|c|c|c|c|c|c|c|c|c|c|c|c|}
\hline \multirow[b]{2}{*}{ Area of protection } & \multicolumn{3}{|c|}{ Asphalt (C-1) } & \multicolumn{3}{|c|}{ Concrete \& Asphalt (C2\&C4) } & \multicolumn{3}{|c|}{ Concrete (C-3) } & \multicolumn{3}{|c|}{ Granite (C5\&C6) } \\
\hline & A1-A3 & A4 & A5 & A1-A3 & A4 & A5 & A1-A3 & A4 & A5 & A1-A3 & A4 & A5 \\
\hline Ecosystem quality & 1.14 & 0.30 & 0.02 & 1.17 & 0.26 & 0.02 & 1.19 & 0.22 & 0.02 & 3.01 & 0.26 & 0.02 \\
\hline Human health & 4.64 & 1.20 & 0.08 & 6.90 & 1.05 & 0.07 & 9.16 & 0.90 & 0.07 & 59.22 & 1.05 & 0.07 \\
\hline Resources & 1.17 & 2.58 & 0.51 & 11.37 & 2.26 & 0.44 & 6.57 & 1.93 & 0.37 & 20.79 & 2.25 & 0.36 \\
\hline Stage representativeness (\%) & $84 \%$ & $16 \%$ & $2 \%$ & $85 \%$ & $15 \%$ & $2 \%$ & $85 \%$ & $15 \%$ & $2 \%$ & $96 \%$ & $4 \%$ & $1 \%$ \\
\hline
\end{tabular}

By emphasizing the weight of each of the categories evaluated by the Ecoindicator 99 (Fig. 7), it was found that the greatest impact of the materials used was on the exhaustion of fossil fuel supplies, respiratory disorders and climate change. Regarding asphalt, more than $72 \%$ of the impact is due to fossil fuel consumption (RS), $13.53 \%$ to respiratory side effects and $6.33 \%$ to climate change. As it is a petrol derivative, it is considered a non-renewable source. Previous research (Araújo et al., 2014) indicates that the most obvious impact of paving materials is their

261 consumption of natural resources. 


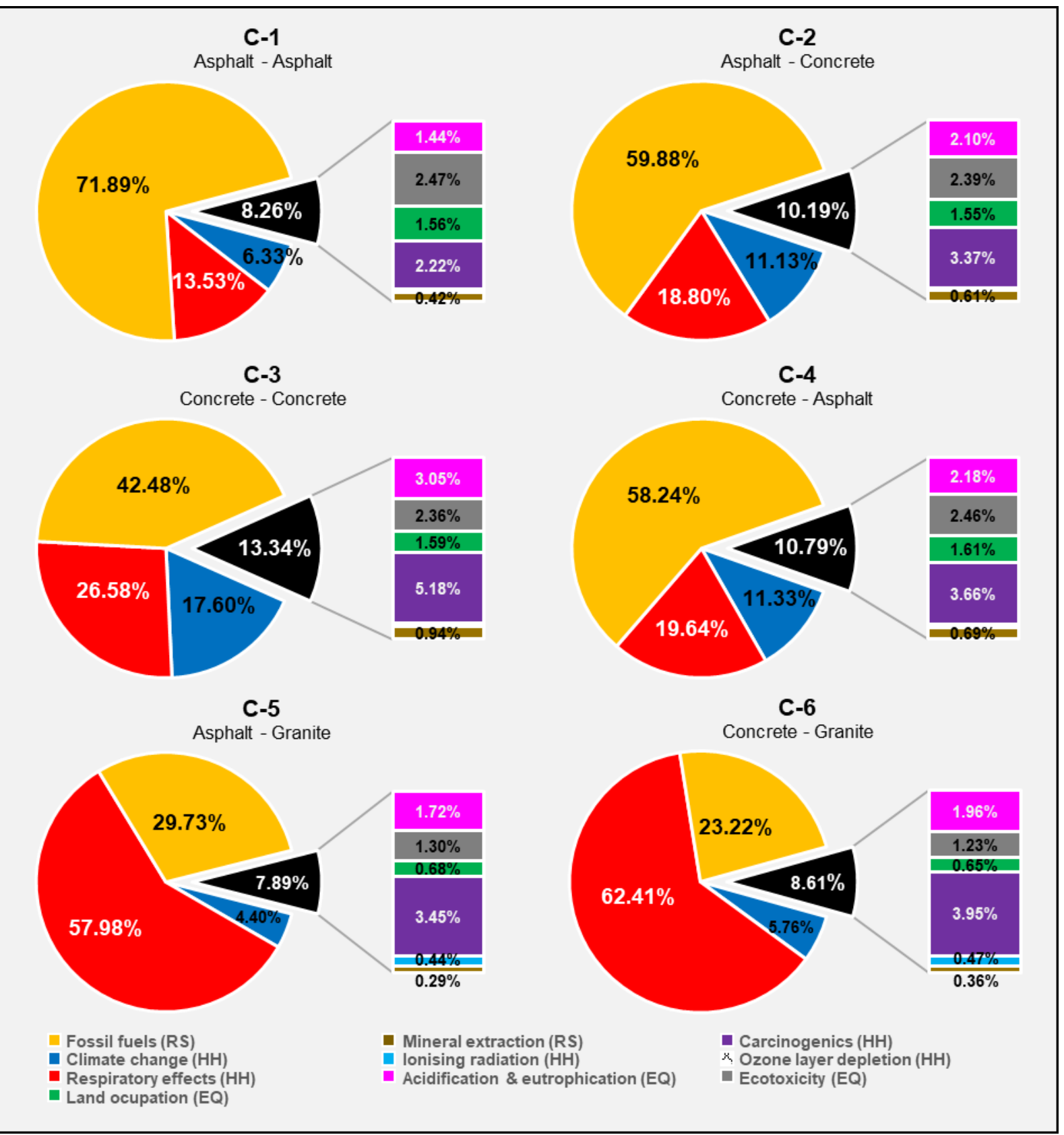

Fig. 7. Percentage corresponding to each impact category, according to the average results of each comparison.

In Fig. 7, it can also be seen that $42.48 \%$ of concrete's environmental impact corresponds to the exhaustion of fossil fuels, $26.58 \%$ to respiratory side effects, $17.60 \%$ to climate change and $5.18 \%$ to carcinogenic effects. The use of fossil fuels is linked to the high temperatures needed in cement production. The emission of particles and volatile elements, such as mercury, is also an inherent part of this industry (Bustillo-Revuelta, 2008) (impact on HH). Previous research has shown that concrete is an important contributor to climate change (Venkatarama 
Reddy \& Jagadish, 2003), due mainly to the GHGs generated by the chemical reactions in clinker production (Damtoft et al., 2008).

Finally, the impact categories most affected by the use of granite (whether combined with asphalt or concrete) are respiratory effects, with almost $60 \%$, climate change with $5 \%$, carcinogenic effects with $3.7 \%(\mathrm{HH})$ and fossil fuel consumption (RS) with $26 \%$ (Fig. 7). Previous studies have attributed the environmental load of human toxicity to the stainless steel used in saw blades, due to their chromium content. Similarly, it has been found that the granite related processes emit significant quantities of GHGs (even more than concrete and asphalt) (Mendoza, Oliver-Solà, Gabarrel, Josa \& Rieradevall, 2012).

\section{Conclusions}

The main findings of this research are as follows. (i) Giving priority to the human scale and promoting non-motorized traffic flow when configuring a residential street can lead to a reduction in the environmental impact generated by the production and construction stages. (ii) It confirms that omitting a detailed analysis of the environmental consequences of material selection for a specific section of street may occasion significant environmental effects. (iii) Applying the LCA in the design phase can lead to a reduction in the environmental effects generated in the production and construction stages of a residential street.

Knowing the impact generated in the production and construction stages of a residential street designed on a human scale, compared with a street that prioritizes motorized traffic (as well as the impact generated by varying the building materials in each zone), It will reinforce the priority (widely demonstrated in the usage stage) by developing a residential street design oriented towards achieving a pedestrian environment. Likewise, the consequences of choosing specific materials are also shown. Obtaining this will be a further step towards developing more sustainable cities. 
Despite the previous guidelines, the use of materials such as granite generates increases in environmental impact of up to $14.9 \%$ for a linear meter of PZ, even when an environment favoring the human scale is prioritized. However, using conventional materials such as concrete and asphalt can generate reductions from $11 \%$ (increasing to $11.5 \% \mathrm{PZ}+\mathrm{BF}$ ) to $22.27 \%$ (increasing to $31 \% \mathrm{PZ}+\mathrm{BZ}+\mathrm{BL}$ ). If the three analyzed materials are compared, granite generates $270 \%$ more environmental damage than concrete and asphalt. The last two, although they have similar general consequences, occasionally show different effects in each of the impact categories studied. For instance, asphalt consumes $121 \%$ more fossil fuels than concrete, which for its part causes $73 \%$ more harm to human health (producing $113 \%, 51 \%$ and $79 \%$ more climate change, respiratory and carcinogenic effects than asphalt).

Finally, it is essential to carry out more analysis such as this, which will include different typologies as well as a wider study of alternative materials (among which, those reincorporated in the life cycle); this will lead to LCA becoming an integral feature of the construction industry with regard to the process of urban planning.

\section{Acknowledgment}

This work was supported by National Council for Science and Technology (CONACYT, by its acronym in Spanish) of Mexico. Acknowledgment also goes to Sinaloa Institute of Support for Research and Innovation (INAPI, by its acronym in Spanish) for making posible the performance of this research.

\section{References}



https://doi.org/10.1016/j.trd.2014.07.006

Biswas, W. K., Alhorr, Y., Lawania, K. K., Sarker, P. K., \& Elsarrag, E. (2017). Life cycle assessment for environmental product declaration of concrete in the Gulf States. Sustain. Cities Soc., 35, 36-46. https://doi.org/10.1016/j.scs.2017.07.011

Bustillo-Revuelta, M. (2008). Hormigones y morteros. (FUEYO EDITORIAL, Ed.). Madrid.

Cass, D., \& Mukherjee, A. (2011). Calculation of greenhouse gas emissions for highway construction operations by using a hybrid life-cycle assessment approach: case study for pavement operations. J. Constr. Eng. Manag., 137(44), 10151026. https://doi.org/10.1061/(ASCE)CO.1943-7862.0000349.

Damtoft, J. S., Lukasik, J., Herfort, D., Sorrentino, D., \& Gartner, E. M. (2008). Sustainable development and climate change initiatives. Cem. Concr. Res., 38, 115-127. https://doi.org/10.1016/j.cemconres.2007.09.008

Faludi, J., Lepech, M. D., \& Loisos, G. (2012). Using Life Cycle Assessment Methods To Guide Architectural DecisionMaking for Sustainable Prefabricated Modular Buildings. J. Green Build., 7, 151-170. https://doi.org/10.3992/jgb.7.3.151

Frischknecht, R., Jungbluth, N., Althaus, H. J., Doka, G., Heck, T., Hellweg, S., Hischier, R., Nemecek, T., Rebitzer, G., Spielmann, M., \& Wernet, G. (2007). Overview and Methodology. (R. Frischknecht \& N. Jungbluth, Eds.), ecoinvent Centre. Dübendorf: Swiss Centre for Life Cycle Inventories. Retrieved from https://www.ecoinvent.org/files/200712_frischknecht_jungbluth_overview_methodology_ecoinvent2.pdf

García-Guaita, F., González-García, S., Villanueva-Rey, P., Moreira, M. T., \& Feijoo, G. (2018). Integrating Urban Metabolism, Material Flow Analysis and Life Cycle Assessment in the environmental evaluation of Santiago de Compostela. Sustain. Cities Soc., 40, 569-580. https://doi.org/10.1016/j.scs.2018.04.027

Gardezi, S. S. S., Shafiq, N., Zawawi, N. A. W. A., Khamidi, M. F., \& Farhan, S. A. (2016). A multivariable regression tool for embodied carbon footprint prediction in housing habitat. Habitat Int., 53, 292-300. https://doi.org/10.1016/j.habitatint.2015.11.005

GDCI, \& NACTO. (2016). Global Street Design Guide. New Forests. ISLAND PRESS.

Gehl, J. (2010). Cities for people. (I. Press, Ed.) (2nd ed.). Washington, DC.

Gilderbloom, J. I., Riggs, W. W., \& Meares, W. L. (2015). Does walkability matter? An examination of walkability's impact on housing values, foreclosures and crime. Cities, 42, 13-24. https://doi.org/10.1016/j.cities.2014.08.001

Haider, H., Hewage, K., Umer, A., Ruparathna, R., Chhipi-Shrestha, G., Culver, K., Holland, M., Kay, J., \& Sadiq, R. (2018). Sustainability assessment framework for small-sized urban neighbourhoods: An application of fuzzy synthetic evaluation. Sustain. Cities Soc., 36, 21-32. https://doi.org/10.1016/j.scs.2017.09.031 
Heinonen, J., Säynäjoki, A., Junnonen, J. M., Pöyry, A., \& Junnila, S. (2016). Pre-use phase LCA of a multi-story residential building: Can greenhouse gas emissions be used as a more general environmental performance indicator? Build. Environ., 95, 116-125. https://doi.org/10.1016/j.buildenv.2015.09.006

ITEC. (2017). Banco BEDEC 2017. Retrieved December 12, 2017, from https://metabase.itec.cat/vide/es/bedec

Kellenberger, D., \& Althaus, H. J. (2009). Relevance of simplifications in LCA of building components. Build. Environ., 44, 818-825. https://doi.org/10.1016/j.buildenv.2008.06.002

Kwan, S. C., \& Hashim, J. H. (2016). A review on co-benefits of mass public transportation in climate change mitigation. Sustain. Cities Soc., 22, 11-18. https://doi.org/10.1016/j.scs.2016.01.004

Lindelöw, D., Svensson, Å., Sternudd, C., \& Johansson, M. (2014). What limits the pedestrian? Exploring perceptions of walking in the built environment and in the context of every-day life. J. Transp. Heal., 1, $223-231$. https://doi.org/10.1016/j.jth.2014.09.002

Loijos, A., Santero, N., \& Ochsendorf, J. (2013). Life cycle climate impacts of the US concrete pavement network. Resour. Conserv. Recycl., 72, 76-83. https://doi.org/10.1016/j.resconrec.2012.12.014

MAC. (2018). Technical Guides - Mastic Asphalt Council. Retrieved March 9, 2018, from http://masticasphaltcouncil.co.uk/technical-guides/

Malmqvist, T., Nehasilova, M., Moncaster, A., Birgisdottir, H., Nygaard Rasmussen, F., Houlihan Wiberg, A., \& Potting, J. (2018). Design and construction strategies for reducing embodied impacts from buildings - Case study analysis. Energy Build., 166, 35-47. https://doi.org/10.1016/j.enbuild.2018.01.033

Mendoza, J. M. F., Oliver-Solà, J., Gabarrell, X., Josa, A., \& Rieradevall, J. (2012). Life cycle assessment of granite application in sidewalks. Int. J. Life Cycle Assess., 17(5), 580-592. https://doi.org/10.1007/s11367-012-0391-1

Mendoza, J. M. F., Oliver-Solà, J., Gabarrell, X., Rieradevall, J., \& Josa, A. (2012). Planning strategies for promoting environmentally suitable pedestrian pavements in cities. Transp. Res. Part D Transp. Environ., 17, 442-450. https://doi.org/10.1016/j.trd.2012.05.008

Ministerio de Fomento. (2017). Inspección y seguridad en el transporte - Pesos y dimensiones. Retrieved January 12, 2017, from https://www.fomento.gob.es/MFOM/LANG_CASTELLANO/DIRECCIONES_GENERALES/TRANSPORTE_TER RESTRE/IGT/PESO/

Mohajerani, A., Ukwatta, A., \& Setunge, S. (2018). Fired-clay bricks incorporating biosolids: Comparative life-cycle assessment. J. Mater. Civ. Eng., 30, 1-12. https://doi.org/10.1061/(ASCE)MT.1943-5533.0002308

Moretti, L., Mandrone, V., Andrea, A. D., \& Caro, S. (2018). Evaluation of the environmental and human health impact of road construction activities. J. Clean. Prod., 172, 1004-1013. https://doi.org/10.1016/j.jclepro.2017.10.250 
Noshadravan, A., Wildnauer, M., Gregory, J., \& Kirchain, R. (2013). Comparative pavement life cycle assessment with parameter uncertainty. Transp. Res. Part D Transp. Environ., 25, 131-138. https://doi.org/10.1016/j.trd.2013.10.002

Oliver-Solà, J., Josa, A., Rieradevall, J., \& Gabarrell, X. (2009). Environmental optimization of concrete sidewalks in urban areas. Int. J. Life Cycle Assess., 14, 302-312. https://doi.org/10.1007/s11367-009-0083-7

Ortiz, O., Pasqualino, J. C., Díez, G., \& Castells, F. (2010). The environmental impact of the construction phase: An application to composite walls from a life cycle perspective. Resour. Conserv. Recycl., 54, 832-840. https://doi.org/10.1016/j.resconrec.2010.01.002

Petit-Boix, A., Sanjuan-Delmás, D., Gasol, C. M., Villalba, G., Suárez-Ojeda, M. E., Gabarrell, X., Josa, A., \& Rieradevall, J. (2014). Environmental Assessment of Sewer Construction in Small to Medium Sized Cities Using Life Cycle Assessment. Water Resour. Manag., 28, 979-997. https://doi.org/10.1007/s11269-014-0528-z

Pré Consultants. (2018). Contribution to Impact Assessment Research | PRé Sustainability. Retrieved March 4, 2018, from https://www.pre-sustainability.com/contribution-to-impact-assessment-research

Pushkar, S. (2014). Using Eco-Indicator 99 to Evaluate Building Technologies under Life Cycle Assessment Uncertainties. J. Archit. Eng., 20, 1-10. https://doi.org/10.1061/(ASCE)AE.1943-5568.0000143

Sandanayake, M., Lokuge, W., Zhang, G., Setunge, S., \& Thushar, Q. (2018). Greenhouse gas emissions during timber and concrete building construction -A scenario based comparative case study. Sustain. Cities Soc., 38, 91-97. https://doi.org/10.1016/j.scs.2017.12.017

Seo, S., Passer, A., Zelezna, J., Hajek, P., Birgisdottir, H., Nygaard Rasmussen, F., Lützkendorf, T., Balouktsi, M., Mistretta, M., Oka, T., Chae, C. U., Houlihan Wiberg, A., Malmqvist, T., Frischknecht, R., \& Moncaster, A. (2016). Overview of Annex 57 Results. In N. Yokoo \& K. Yokoyama (Eds.), Eval. Embodied Energy CO2eq Build. Constr. (Annex 57) (p. 100). Tokyo, Japan: Institute for Building Environment and Energy Conservation. Retrieved from http://www.ecbcs.org/Data/publications/EBC_Annex_57_Results_Overview.pdf

Sianipar, C. P. M., \& Dowaki, K. (2014). Eco-burden in pavement maintenance: Effects from excess traffic growth and overload. Sustain. Cities Soc., 12, 31-45. https://doi.org/10.1016/j.scs.2014.01.002

Simpple. (2010). Manual de usuario LCAmanager versión 1.3. Tarragona, Spain.

Smith, S. H., \& Durham, S. A. (2016). A cradle to gate LCA framework for emissions and energy reduction in concrete pavement mixture design. Int. J. Sustain. Built Environ., 5, 23-33. https://doi.org/10.1016/j.ijsbe.2016.01.001

Thiers, S., \& Peuportier, B. (2012). Energy and environmental assessment of two high energy performance residential buildings. Build. Environ., 51, 276-284. https://doi.org/10.1016/j.buildenv.2011.11.018

Venkatarama Reddy, B. V., \& Jagadish, K. S. (2003). Embodied energy of common and alternative building materials and technologies. Energy Build., 35, 129-137. https://doi.org/10.1016/S0378-7788(01)00141-4 


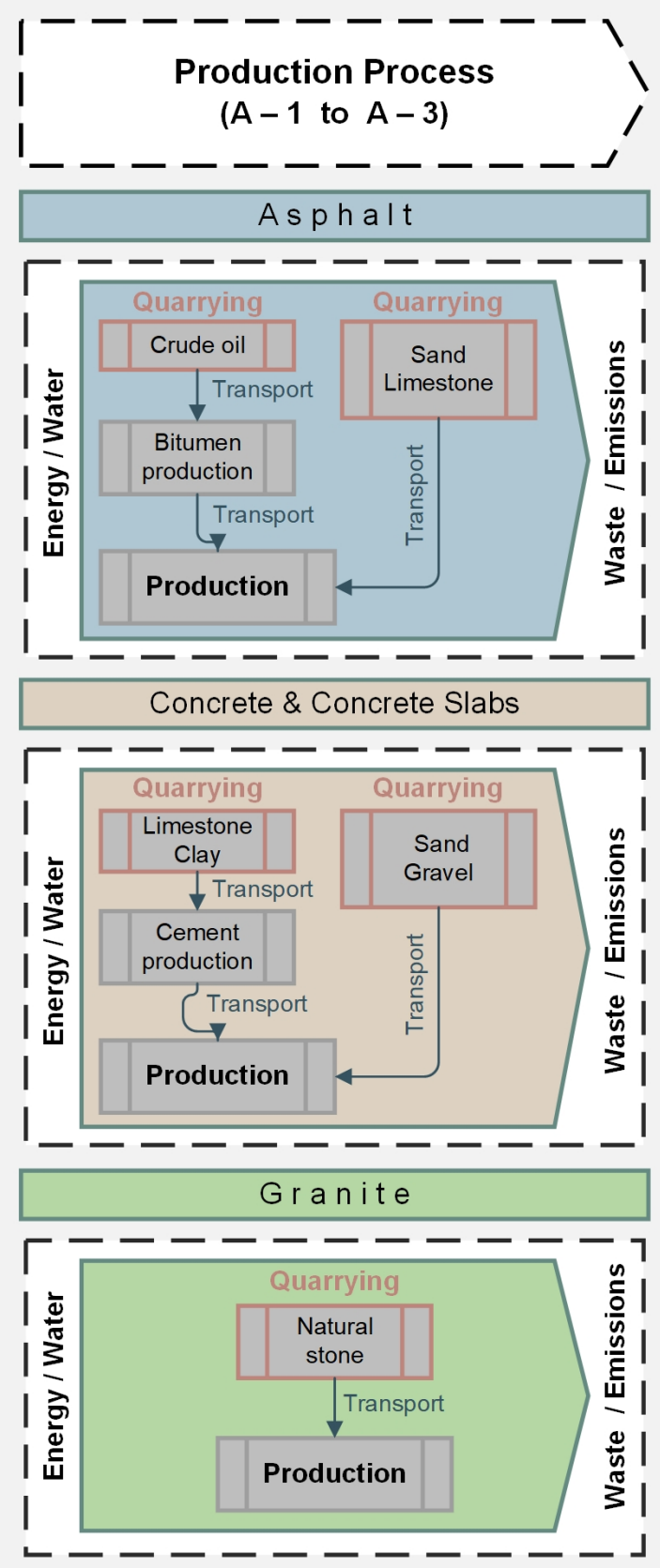

Construction Process

$(A-4$ to $A-5)$

\section{Transport from facility to site}
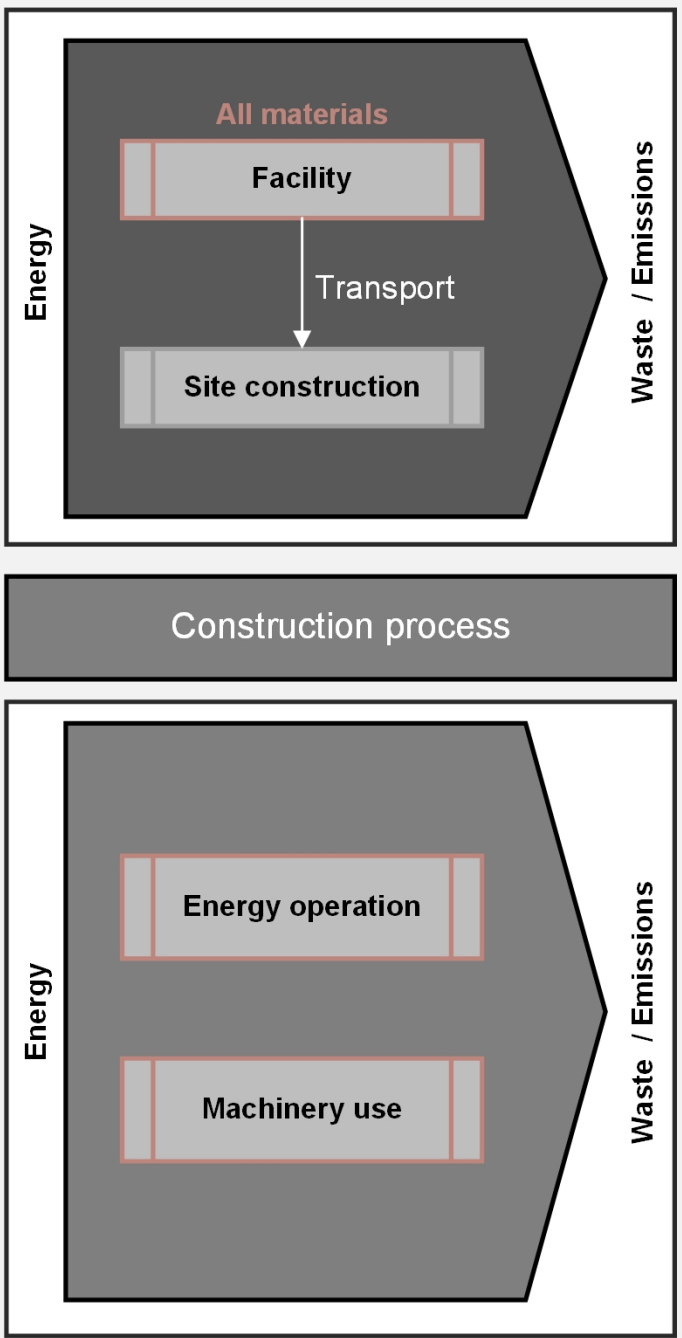


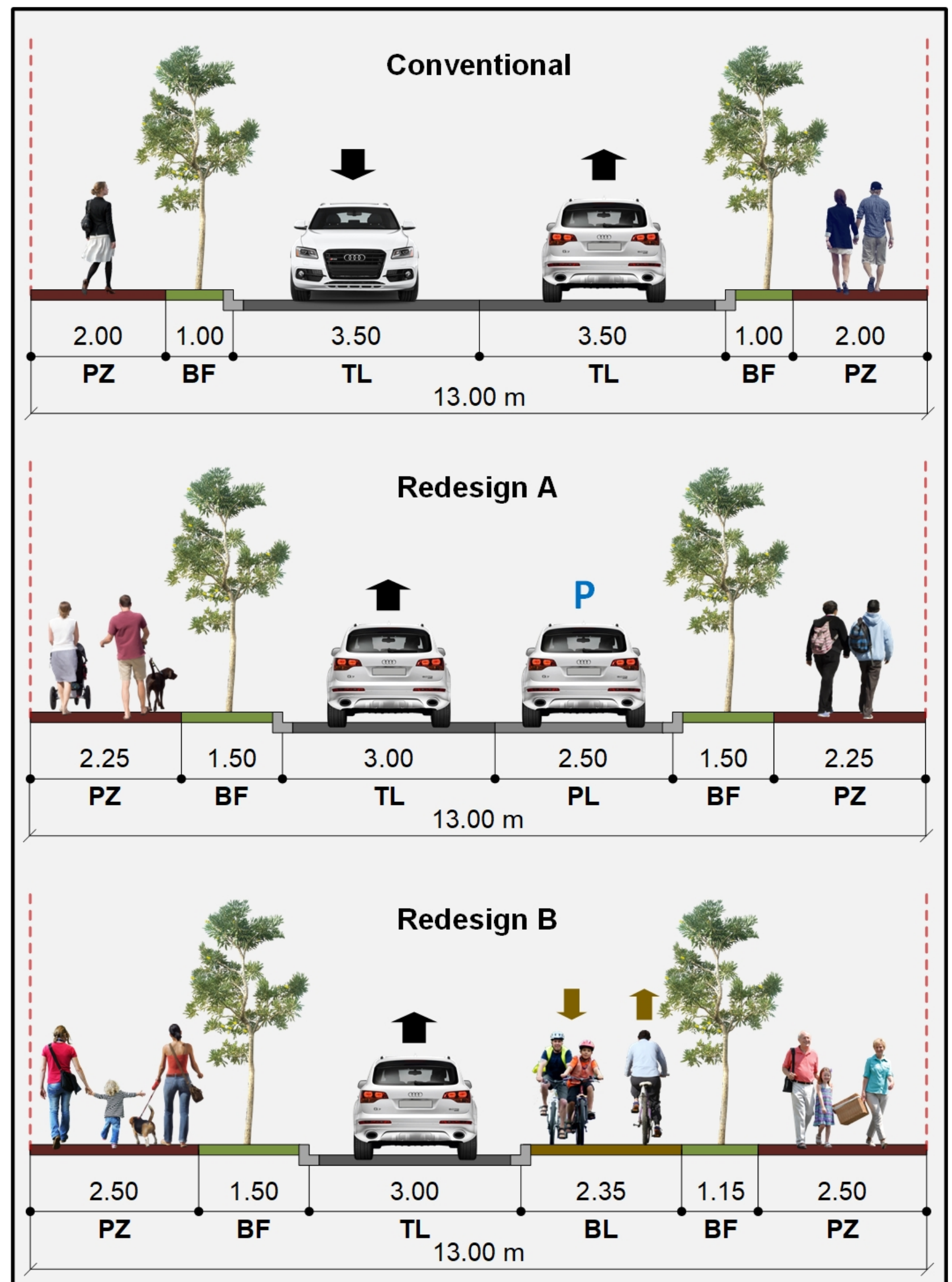

Abreviations: PZ: Pedestrian Zone; BF: Buffer Zone; TL: Travel Lane; PL: Parking Lane; BL: Bicycle Lane. 


\section{Sidewalk layers:}

Asphalt (PZ \& BL):

Mastic asphalt, $2.5 \mathrm{~cm}$;

Granular base, $15 \mathrm{~cm}$;

Subgrade

Concrete slabs (PZ):

Concrete slabs, $6 \mathrm{~cm}$;

Granular base, $15 \mathrm{~cm}$;

Subgrade

Granite (PZ):

Granite slabs, $7 \mathrm{~cm}$;

Mortar base, $3 \mathrm{~cm}$;

Concrete base, $10 \mathrm{~cm}$;

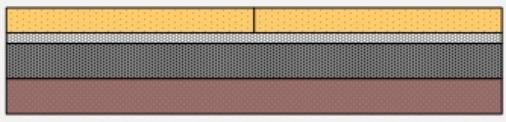

Subgrade

\section{Concrete (BL):}

Concrete layer, $16 \mathrm{~cm}$;

Granular base, $10 \mathrm{~cm}$;

Subgrade

\section{Street layers:}

Asphalt (TL \& PL):

Mastic asphalt, $3.5 \mathrm{~cm}$;

Granular base, $20 \mathrm{~cm}$;

Sub-base material, $15 \mathrm{~cm}$;

Subgrade

\section{Concrete (TL \& PL):}

Concrete layer, $18 \mathrm{~cm}$;

Granular base, $15 \mathrm{~cm}$;

Subgrade

\section{Abbreviations:}

Bicyle Lane (BL)

Parking Lane (PL)

Pedestrian Zone (PZ)

Travel Lane (TL) 


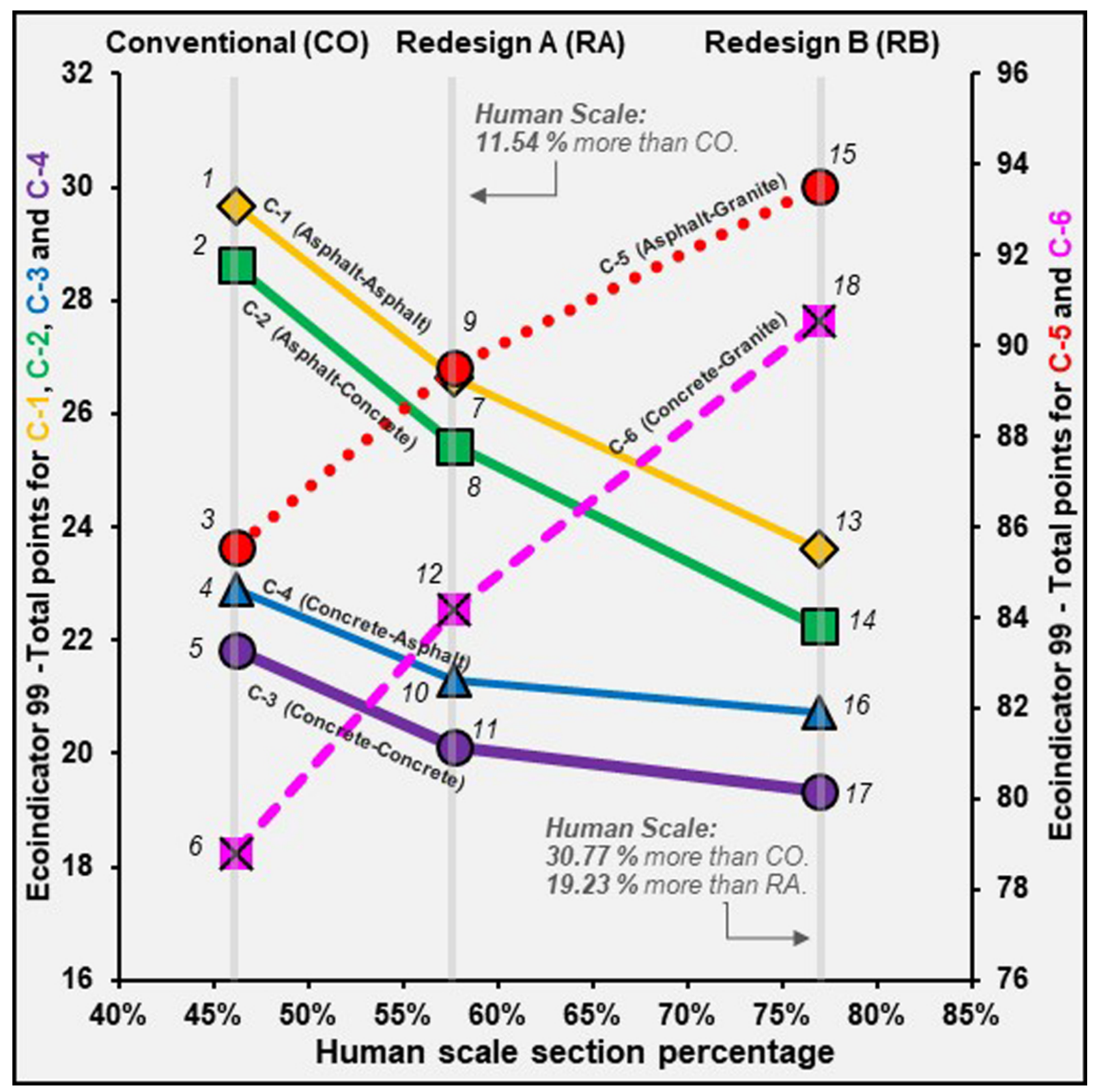




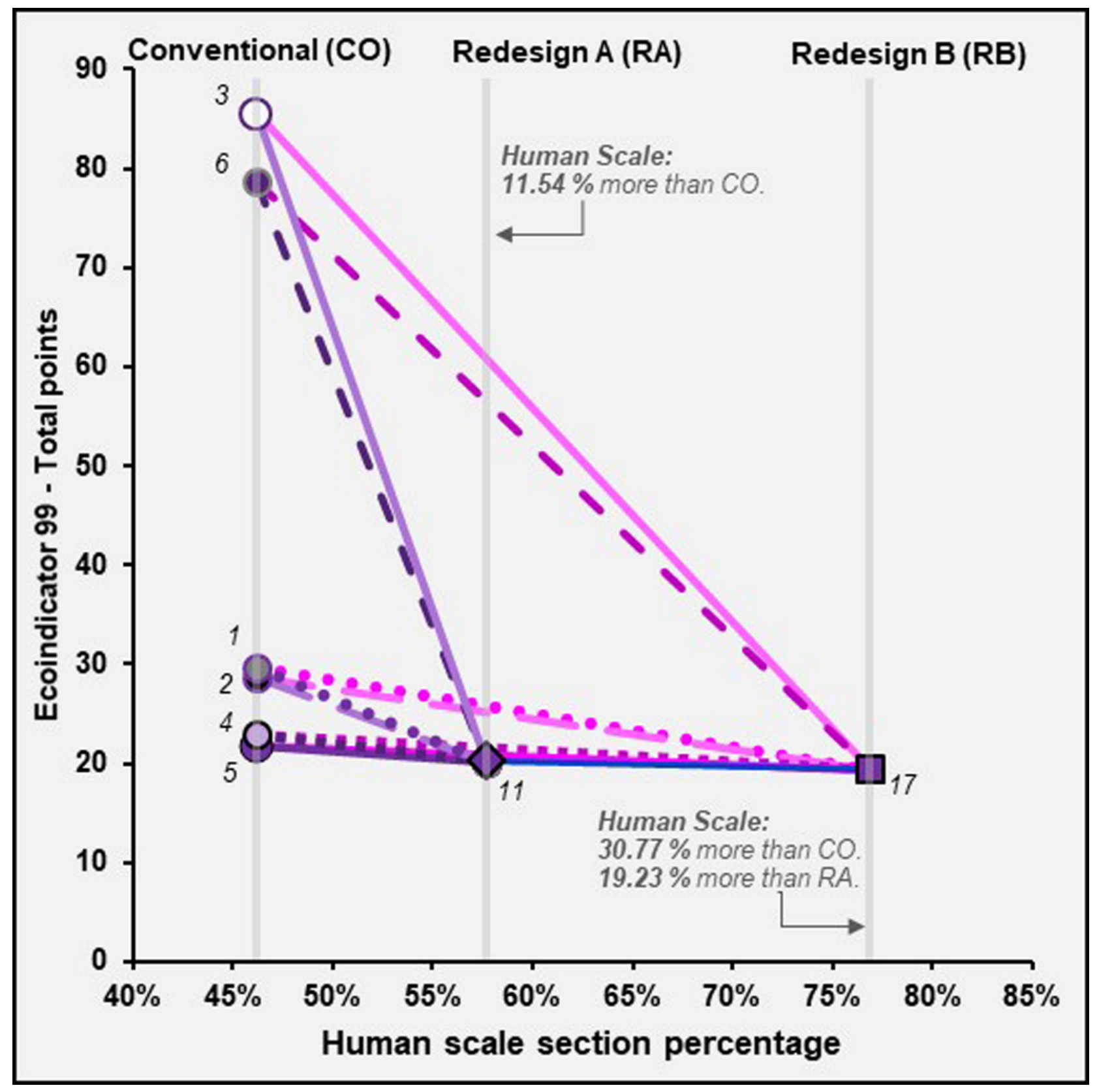




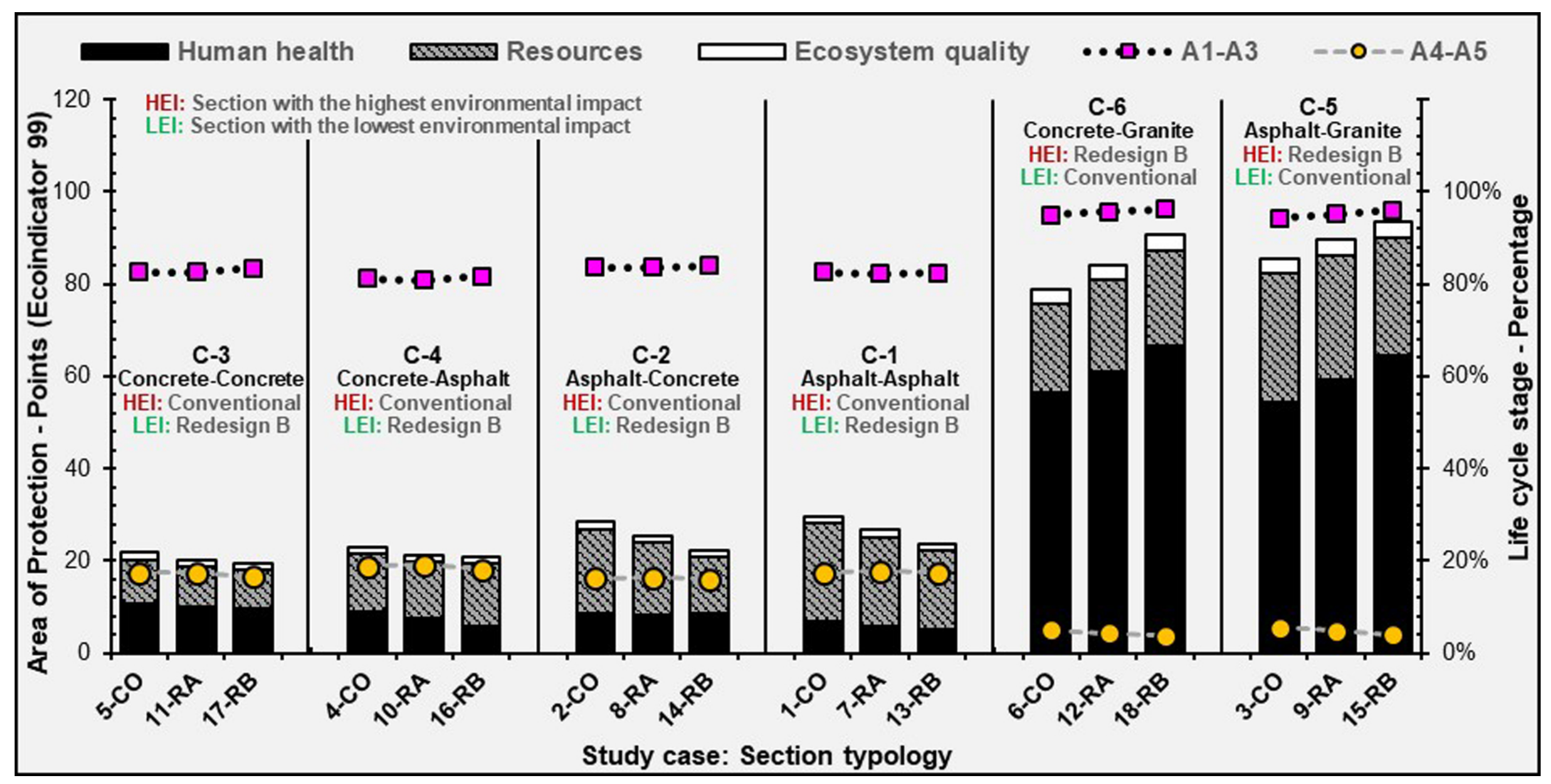




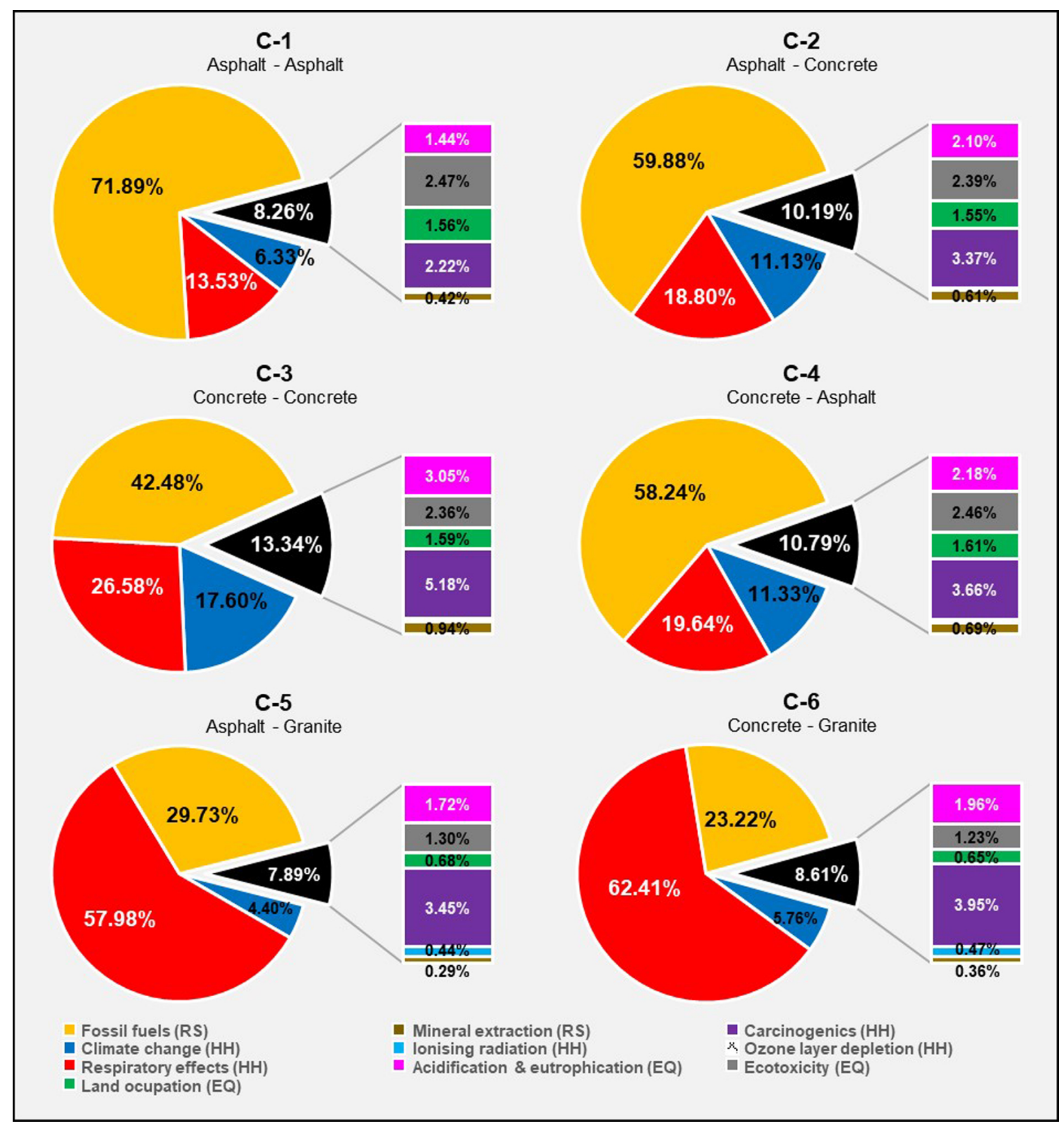


Table 1

LCA studies that consider the stages directly related to the construction process.

\begin{tabular}{lll}
\hline Stage & Authors & Highlights \\
\hline Cradle to gate & (Cass \& Mukherjee, 2011) & Development of a method that quantifies pavement life cycle emissions. \\
(A1-A3) & (Moretti et al., 2018) & Analysis of environmental impacts of two types of road cross-sections. \\
& (Sandanayake et al., 2018) & Comparison of greenhouse gas (GHG) emissions and energy consumption in wood and \\
& concrete buildings. \\
Cradle to site & (Gardezi et al., 2016) & Development of an embodied carbon prediction tool for conventional housing. \\
(A1-A3+A4) & (Smith \& Durham, 2016) & Environmental evaluation of pavements considering economic, environmental and \\
Cradle to handover & mechanical performance criteria. \\
(A1-A3+A4-A5) & (Mohajerani et al., 2018) & Evaluation of the impacts generated by the incorporation of biosolids in conventional \\
& & materials. \\
\hline
\end{tabular}




\section{Table 2}

LCI for functional unit (one linear meter) of each street zone.

\begin{tabular}{|c|c|c|c|c|c|c|c|c|c|c|c|c|c|c|c|c|c|c|c|}
\hline \multirow[t]{2}{*}{ Stage } & \multirow[t]{2}{*}{ Material/process } & \multicolumn{5}{|c|}{ Conventional } & \multicolumn{5}{|c|}{ Redesign A } & \multicolumn{7}{|c|}{ Redesign B } & \multirow[t]{2}{*}{ Ecoinvent material/process } \\
\hline & & $\begin{array}{l}\mathrm{TL} \\
\text { Asphalt }\end{array}$ & $\begin{array}{l}\mathrm{TL} \\
\text { Concrete }\end{array}$ & $\begin{array}{l}\mathrm{PZ}+ \\
\mathrm{BZ} \\
\text { Asphalt }\end{array}$ & $\begin{array}{l}\mathrm{PZ}+\mathrm{BZ} \\
\text { Concrete }\end{array}$ & $\begin{array}{l}\text { PZ+BZ } \\
\text { Granite }\end{array}$ & $\begin{array}{l}\mathrm{TL}+\mathrm{PL} \\
\text { Asphalt }\end{array}$ & $\begin{array}{l}\mathrm{TL}+\mathrm{PL} \\
\text { Concrete }\end{array}$ & $\begin{array}{l}\mathrm{PZ}+ \\
\mathrm{BZ} \\
\text { Asphalt }\end{array}$ & $\begin{array}{l}\mathrm{PZ}+\mathrm{BZ} \\
\text { Concrete }\end{array}$ & $\begin{array}{l}\text { PZ+BZZ } \\
\text { Granite }\end{array}$ & $\begin{array}{l}\text { TL } \\
\text { Asphalt }\end{array}$ & $\begin{array}{l}\text { TL } \\
\text { Concrete }\end{array}$ & $\begin{array}{l}\mathrm{PZ}+ \\
\mathrm{BZ} \\
\text { Asphalt }\end{array}$ & $\begin{array}{l}\mathrm{PZ}+\mathrm{BZ} \\
\text { Concrete }\end{array}$ & $\begin{array}{l}\text { PZ+BZ } \\
\text { Granite }\end{array}$ & $\begin{array}{l}\text { BL } \\
\text { Asphalt }\end{array}$ & $\begin{array}{l}\mathrm{BL} \\
\text { Concrete }\end{array}$ & \\
\hline \multirow{9}{*}{$\begin{array}{l}\text { A1- } \\
\text { A3 }\end{array}$} & Water (kg) & 89.78 & 60.38 & 34.50 & - & 25.20 & 70.54 & 47.44 & 38.81 & - & 28.35 & 38.48 & 25.88 & 43.13 & - & 31.50 & 18.11 & 12.08 & Tap water, at user \\
\hline & Coarse aggregates (ton) & 3.98 & 2.05 & 1.17 & - & - & 3.13 & 1.61 & 1.32 & - & - & 1.71 & 0.88 & 1.47 & - & - & 0.62 & 410.55 & Gravel, crushed, at mine \\
\hline & Cement (kg) & 129.65 & - & - & - & 31.50 & 101.87 & - & - & - & 35.44 & 55.57 & - & - & - & 39.38 & - & - & Portland cement, strength class Z 42.5 , at plant \\
\hline & Concrete base $\left(\mathrm{m}^{3}\right)$ & - & - & - & 0.42 & 0.42 & - & - & - & 0.47 & 0.47 & - & - & - & 0.53 & 0.53 & - & - & Concrete, normal, at plant \\
\hline & Fine aggregates $(\mathrm{kg})$ & - & - & - & 24.81 & 205.38 & - & - & - & 27.91 & 231.05 & - & - & - & 31.01 & 256.73 & - & - & Silica sand, at plant \\
\hline & Asphalt (kg) & 540.23 & - & 220.50 & - & - & 424.46 & - & 248.06 & - & - & 231.53 & - & 275.63 & - & - & 115.76 & - & Mastic asphalt, at plant \\
\hline & $\begin{array}{l}\text { Concrete/concrete slabs } \\
\left(\mathrm{m}^{3}\right)\end{array}$ & - & 1.32 & - & 0.33 & - & - & 1.04 & - & 0.37 & - & - & 0.57 & - & 0.41 & - & - & 0.35 & Concrete, exacting, at plant \\
\hline & Granite slabs (kg) & - & - & - & - & 742.56 & - & - & - & - & 835.38 & - & - & - & - & 928.20 & - & - & Natural stone plate, polished, at regional storage \\
\hline & Sand $(\mathrm{kg})$ for $\mathrm{BZ}$ & - & - & 444.00 & 473.60 & 444.00 & - & - & 744.00 & 793.60 & 744.00 & - & - & 714.00 & 875.60 & 714.00 & - & - & Silica sand, at plant \\
\hline $\mathrm{A} 4$ & Operation lorry (tkm) & 253.40 & 181.38 & 101.87 & 77.11 & 87.78 & 199.10 & 142.51 & 129.27 & 102.39 & 113.42 & 108.60 & 77.73 & 136.88 & 113.40 & 119.26 & 39.50 & 41.71 & Transport, lorry 16-32t, EURO5 \\
\hline \multirow[t]{3}{*}{$\overline{\mathrm{A} 5}$} & Machinery E10-6 (unit) & 20.56 & 38.80 & 7.65 & 0.65 & 8.82 & 16.15 & 30.49 & 8.61 & 0.73 & 9.92 & 8.81 & 16.63 & 9.56 & 0.82 & 11.03 & 4.02 & 9.54 & Building machine \\
\hline & Energy (kg) & 2.38 & 2.46 & 0.86 & 0.01 & - & 1.87 & 1.93 & 0.97 & 0.01 & - & 1.02 & 1.06 & 1.07 & 0.01 & - & 0.45 & 0.57 & Diesel, at regional storage \\
\hline & Energy (kWh) & - & - & - & - & 0.06 & - & - & - & - & 0.07 & - & - & - & - & 0.08 & - & - & Electricity, low voltage, production ES, at grid / ES \\
\hline
\end{tabular}




\section{Table 3}

Fuel consumption or potency of machinery.

\begin{tabular}{ll}
\hline Machine & $\begin{array}{l}\text { Fuel consumption }(\mathrm{kg} / \mathrm{h}) \\
\text { or potency }(\mathrm{kW})\end{array}$ \\
\hline Tanker truck $10 \mathrm{~m}^{3}$ & 8.3 \\
Vibratory roller & 10.8 \\
Motor Grader & 14.1 \\
Dumper & 2.2 \\
Asphalt paver & 8.7 \\
Concrete paver & 11.4 \\
Vibrating tray & 1.2 \\
Concrete mixer & 0.7 \\
\hline
\end{tabular}

\section{Table 4}

Case studies description.

\begin{tabular}{|c|c|c|c|}
\hline Typology & Case & Zone - Total Width (m) - Material & $\begin{array}{l}\text { Most common material in: } \\
\mathrm{MF}^{\mathrm{A}} \text { zones }-\mathrm{GM}^{\mathrm{B}} \text { zones }\end{array}$ \\
\hline \multirow[t]{6}{*}{ Conventional } & 1 & TL-7.00-Asphalt; PZ-4.00-Asphalt; BZ-2.00-Sand & Asphalt - Asphalt \\
\hline & 2 & TL-7.00-Asphalt; PZ-4.00-Concrete; BZ-2.00-Sand & Asphalt - Concrete \\
\hline & 3 & TL-7.00-Asphalt; PZ-4.00-Granite; BZ-2.00-Sand & Asphalt - Granite \\
\hline & 4 & TL-7.00-Concrete; PZ-4.00-Asphalt; BZ-2.00-Sand & Concrete - Asphalt \\
\hline & 5 & TL-7.00-Concrete; PZ-4.00-Concrete; BZ-2.00-Sand & Concrete - Concrete \\
\hline & 6 & TL-7.00-Concrete; PZ-4.00-Granite; BZ-2.00-Sand & Concrete - Granite \\
\hline \multirow[t]{6}{*}{ Redesign A } & 7 & TL \& PL-5.50-Asphalt; PZ-4.50-Asphalt; BZ-3.00-Sand & Asphalt - Asphalt \\
\hline & 8 & TL \& PL-5.50-Asphalt; PZ-4.50-Concrete; BZ-3.00-Sand & Asphalt - Concrete \\
\hline & 9 & TL \& PL-5.50-Asphalt; PZ-4.50-Granite; BZ-3.00-Sand & Asphalt - Granite \\
\hline & 10 & TL \& PL-5.50-Concrete; PZ-4.50-Asphalt; BZ-3.00-Sand & Concrete - Asphalt \\
\hline & 11 & TL \& PL-5.50-Concrete; PZ-4.50-Concrete; BZ-3.00-Sand & Concrete - Concrete \\
\hline & 12 & TL \& PL-5.50-Concrete; PZ-4.50-Granite; BZ-3.00-Sand & Concrete - Granite \\
\hline \multirow[t]{6}{*}{ Redesign B } & 13 & TL-3.00-Asphalt; PZ-5.00-Asphalt; BL-2.35-Asphalt; BZ-2.65-Sand & Asphalt - Asphalt \\
\hline & 14 & TL-3.00-Asphalt; PZ-5.00-Concrete; BL-2.35-Concrete; BZ-2.65-Sand & Asphalt - Concrete \\
\hline & 15 & TL-3.00-Asphalt; PZ-5.00-Granite; BL-2.35-Asphalt; BZ-2.65-Sand & Asphalt - Granite \\
\hline & 16 & TL-3.00-Concrete; PZ-5.00-Asphalt; BL-2.35-Asphalt; BZ-2.65-Sand & Concrete - Asphalt \\
\hline & 17 & TL-3.00-Concrete; PZ-5.00-Concrete; BL-2.35-Concrete; BZ-2.65-Sand & Concrete - Concrete \\
\hline & 18 & TL-3.00-Concrete; PZ-5.00-Granite; BL-2.35-Concrete; BZ-2.65-Sand & Concrete - Granite \\
\hline
\end{tabular}




\section{Table 5}

Comparatives showing similar ratios of materials.

\begin{tabular}{lll}
\hline Comparative & $\begin{array}{l}\text { Most common material in: } \\
\text { MF }\end{array}$ & Case - Section typology \\
& & \\
\hline C-1 & Asphalt - Asphalt & \\
C-2 & Asphalt - Concrete & 1-CO ; 7-RA ; 13-RB \\
C-3 & Concrete - Concrete & 2-CO ; 8-RA ; 14-RB \\
C-4 & Concrete - Asphalt & 5-CO ; 11-RA ; 17-RB \\
C-5 & Asphalt - Granite & 4-CO ; 10-RA ; 16-RB \\
C-6 & Concrete - Granite & 3-CO ; 9-RA ; 15-RB
\end{tabular}

${ }^{\mathrm{A}}$ Motorized flow; TL \& PL ${ }^{\mathrm{B}}$ Green mobility; PZ \& BL.

\section{Table 6}

Values of Ecoindicator 99 for the most important impact categories for concrete and asphalt.

\begin{tabular}{lll}
\hline Impact Category & C-1 (Concrete) & C-3 (Asphalt) \\
\hline Carcinogenic & 1.06 & 0.59 \\
Climate change & 3.60 & 1.69 \\
Respiratory effects & 5.43 & 3.60 \\
Fossil fuels & 8.68 & 19.16 \\
Total & 20.43 & 26.65 \\
\hline
\end{tabular}

Table 7

Values of Ecoindicator 99 for the AoP of the life cycle stages.

\begin{tabular}{|c|c|c|c|c|c|c|c|c|c|c|c|c|}
\hline \multirow[b]{2}{*}{ Area of protection } & \multicolumn{3}{|c|}{ Asphalt (C-1) } & \multicolumn{3}{|c|}{ Concrete \& Asphalt (C2\&C4) } & \multicolumn{3}{|c|}{ Concrete (C-3) } & \multicolumn{3}{|c|}{ Granite (C5\&C6) } \\
\hline & A1-A3 & A4 & A5 & A1-A3 & A4 & A5 & A1-A3 & A4 & A5 & A1-A3 & A4 & A5 \\
\hline Ecosystem quality & 1.14 & 0.30 & 0.02 & 1.17 & 0.26 & 0.02 & 1.19 & 0.22 & 0.02 & 3.01 & 0.26 & 0.02 \\
\hline Human health & 4.64 & 1.20 & 0.08 & 6.90 & 1.05 & 0.07 & 9.16 & 0.90 & 0.07 & 59.22 & 1.05 & 0.07 \\
\hline Resources & 1.17 & 2.58 & 0.51 & 11.37 & 2.26 & 0.44 & 6.57 & 1.93 & 0.37 & 20.79 & 2.25 & 0.36 \\
\hline Stage representativeness (\%) & $84 \%$ & $16 \%$ & $2 \%$ & $85 \%$ & $15 \%$ & $2 \%$ & $85 \%$ & $15 \%$ & $2 \%$ & $96 \%$ & $4 \%$ & $1 \%$ \\
\hline
\end{tabular}

